\title{
ORÍGENES DEL ARCHIVO DE LA CORONA DE ARAGÓN, (EN TIEMPOS, ARCHIVO REAL DE BARCELONA)
}

\author{
CARLOS LÓPEZ RODRÍGUEZ \\ Director del Archivo de la Corona de Aragón
}

RESUMEN: El Archivo de la Corona de Aragón quizá sea la institución archivística viva más antigua de Europa. Cierta bibliografía ha remontado sus orígenes a la bipotética existencia de un archivo creado por los condes de Barcelona en el siglo X. Sin embargo, las evidencias documentales obligan a retrasar su fundación hasta 1318, en el marco de las transformaciones políticas y burocráticas introducidas por Jaime II en la Corona de Aragón, que bicieron de esta agregación dinástica de reinos una unidad política sustantiva. Con anterioridad, ya Jaime I habia dispuesto de varios depósitos documentales en algunos monasterios, como el de Sijena, que era también panteón real, pero con notorias limitaciones, desde el punto de vista jurídico y burocrático. Hasta entrado el siglo XIII, tras la recepción y difusión del Derecho común, no se concibe el archivo como un lugar privilegiado de fe pública, que es atributo del príncipe y marca de soberanía, por las implicaciones jurídicas que contiene. Fue sólo a principios del siglo XIV cuando confluyeron en la Corona de Aragón custodia de documentos, gestión de la información y fe pública, los tres vectores que convirtieron los archivos bajomedievales y modernos de la Monarquía en eficaces instrumentos para el ejercicio del Poder.

Palabras Clave: Archivo de la Corona de Aragón. Archivos. Fe pública. Poder político. Jaime II. Corona de Aragón. Barcelona.

ABSTRACT: The Archive of the Crown of Aragon is probably the most ancient institution of its kind still alive in Europe. Its origins have been traced back by some historians to the bypothetical existence of an archive created by the counts of Barcelona in $10^{\text {th }}$ century. However, there is no documental evidence of its existence until 1318, in the framework of the political and bureaucratic transformations introduced by king James II of the Crown of Aragon, which enforced the political confederation born as a loose dynastic union. Previously, James I had kept records in several monasteries, such as Sijena, also a royal pantheon, but in a very limited way from the organisational and legal point of view. It is only after the reception of Roman law, in the 
middle of $13^{\text {th }}$ century, when archives begin to be thought of as privileged places to keep records that bear witness, as a royal prerogative and as a sign of authority. Only at the beginning of the $14^{\text {th }}$ century were the concepts of recordkeeping, information management and documents as a source of evidence brought together within the Crown of Aragon and led to a transformation of the medieval archival institutions into useful instruments of power for the Monarchy.

KEY WORDS: Archive of the Crown of Aragon. Records. evidence. political power. James II. Crown of Aragon. Barcelona.

¿Qué es el Archivo de la Corona de Aragón (ACA)? Quizá sea la institución archivística más antigua de Europa. Tanto, que su nombre originario, hace setecientos años, no fue este, sino simplemente el de Archivo Real. A decir verdad, pese a su existencia secular, hasta el siglo XVIII careció de nombre oficial, como hoy concebimos que lo debería tener una institución del Estado. Por eso puede parecer tan confusa su trayectoria, si se adopta un punto de vista simplista o deliberadamente reduccionista ${ }^{1}$. Y, sin embargo, pocos centros culturales disponen de tantos materiales para su estudio como el ACA. Esto permite no precipitarse a la hora de valorar en sus justos términos la compleja historia de esta centenaria institución. Hay que leer con atención y sin telarañas en los ojos la bibliografía existente, los documentos publicados y aquellos otros exhumados por eruditos que dedicaron toda su vida al estudio de este tema. Fue el caso de Rafael Conde y Delgado de Molina. Durante treinta y seis años y hasta su fallecimiento en marzo de 2005, vivió, más que trabajó, en el ACA. Nos ha legado una obra inmensa que esperemos que toda ella pueda salir pronto a la luz. A sus escritos publicados y a los que aparecerán póstumamente nos remitimos para este trabajo. También a su concepción de la historia del ACA, aunque discrepemos en algunos puntos que iremos señalando. Aparte de las publicaciones que indicaremos, Rafael Conde ha dejado dos obras de una importancia capital para los Archivos españoles. Uno de ellas se titula Reyes y archivos en la Corona de Aragón. Siete siglos de reglamentación y praxis archivística (siglos XII-XIX), que contiene 157 páginas de estudio introductorio más 284 documentos transcritos. Constituye un compendio sobre lo que se sabe de este asunto. La otra, de menor volumen, llamada El archivo real del monasterio de Santa María de Sijena (Huesca). Primer tercio del s. XIII-1308, tiene 65 páginas de estudio más 26 documentos transcritos en 80 páginas. Las usaremos con profusión. Ambas esperan su publicación. En parte, este artículo, además de rendir homenaje a Rafael Conde, pretende llamar la atención sobre el interés extraordinario que tienen. Gracias a su inmenso e inteligente trabajo de búsqueda de documentos, de recopilación de materiales, de sistematización y de

${ }^{1}$ Una visión de conjunto de este archivo, en Udina MARTORELl, Federico: Guía histórica y descriptiva del Archivo de la Corona de Aragón. Madrid, Dirección General de Bellas Artes y Archivos, 1986, 490 págs. 
contextualización, podemos rastrear con más seguridad los orígenes del ACA. Nos permite también introducir algunas precisiones y mantener algunas pequeñas diferencias con las líneas generales que trazó sobre su historia.

Nuestro punto de partida será el análisis de la especie que, en determinados medios profesionales e historiográficos catalanes, ha prendido acerca de la existencia un «archivo condal», en el que se custodió parte de la rica documentación de esa época que hoy se conserva en el $\mathrm{ACA}^{2}$. Para estos autores, el nombre «Archivo de la Corona de Aragón» es una denominación impropia que se impuso al Archivo Real de Barcelona (ARB) en el siglo XVIII. Este Archivo Real de Barcelona remonta sus orígenes al siglo IX, como «archivo condal» que se continuó hasta la unión dinástica con Aragón en 1137. En ese momento, el viejo "archivo condal» se convertiría en "Archivo Real de Barcelona», que se trasladó al Palacio Real de Barcelona en 1318. Este archivo real sólo lo sería de la Corona de Aragón desde entonces hasta la creación de los archivos reales de Valencia en 1419 y de Zaragoza en 1461. A esta institución impondría la tiranía borbónica un nuevo nombre y unas nuevas funciones como archivo general de la antigua Corona de Aragón, que sólo se habrían realizado de modo muy deficiente e incompleto. Aquí se mezclan dos cuestiones. Una, subyacente, de carácter político (acerca de las competencias autonómicas y de una reclamación nacionalista), y otra, la histórica, que en este caso es meramente voluntarista. Es en este punto donde debe intervenir la estricta crítica historiográfica, basada en datos documentales fehacientes. Si el estudio de los orígenes de una institución o proceso histórico constituye un problema de importancia capital, más aún en este caso.

\section{LA CUESTIÓN DEL «ARCHIVO CONDAL»}

Ya E. González Hurtebise afirmó que sería temerario sostener que todas las escrituras sueltas, originales en pergaminos, anteriores a la devastación de Barcelona por Almanzor en 985, constituyeron el Archivo primitivo ${ }^{3}$ La expresión «Archivo condal» para referirse a los fondos más antiguos conservados en la

2 Un ejemplo extremado de esta posición puede consultarse en Ramon Planes, Laureà Pagaroles y Pere Puig, L'Arxiu de la Corona d'Aragó: Un nou perfil per a l'Arxiu Reial de Barcelona, Barcelona, 2003, donde queda de manifiesto las consecuencias patrimoniales y políticas que desde tales planteamientos se da a la existencia de un «archivo condal».

3 GonZÁlez Hurtebise, Eduardo: «Guía histórico-descriptiva del Archivo de la Corona de Aragón», en Guía histórica y descriptiva de los Archivos, Bibliotecas y Museos Arqueológicos de España que están a cargo del Cuerpo Facultativo del Ramo, publicada bajo la dirección del Excmo. Sr. D. Francisco Rodríguez Marín, Jefe del Cuerpo y Director de la Biblioteca Nacional. Sección de Archivos. Archivos Históricos. Madrid, Tipografía de la Revista de Archivos, Bibliotecas y Museos, 1916, p. 3. Interesan para el período que aquí se estudia las pp. 3-15, en las que se citan muchos de los documentos recogidos y transcritos después por $\mathrm{R}$. Conde en sus dos trabajos inéditos ya mencionados. 
sección de Cancillería del ACA la consagró Federico Udina Martorell en un conocido, meritorio y en algunos aspectos pionero trabajo sobre los pergaminos custodiados en este Archivo hasta la muerte del conde Borrel II, acaecida en $992^{4}$. Tras un detenido examen, F. Udina determinó que de los 242 documentos que estudia, sólo unos veinte —a juzgar por los recopilados en el Liber Feudorum Maior - integraron el núcleo básico de lo que él pensaba que era el Archivo en el siglo XII. El resto ingresó más tarde y se mezcló con los primitivos fondos 5 . Por eso, es posible determinar diversos grupos de pergaminos que tienen distintas procedencias. El más destacable — que incluye los pergaminos de Wifredo Iviene del monasterio de Sant Joan de les Abadesses, y fue ingresado en el Archivo Real de Barcelona en el s. XVII ${ }^{6}$. Pero hay otros como los de Olérdola o los de Provençals. En resumen, concluye, en el «Archivo condal del siglo XII se conservarían unos cuarenta documentos de los siglos IX y X (dieciséis del Liber, más unos veinticinco o treinta)» ${ }^{7}$. Pese a lo cual mantiene el título de «Archivo condal» para su trabajo. Por ahora, baste señalar que poco archivo sería aquel que hubiera reunido nada más que unos cuarenta documentos en dos siglos.

Rafael Conde añade, por su parte, otras cuentas. De los sesenta y tres pergaminos que han llegado hasta hoy anteriores al año 993 y que según el estudio de Udina debían estar en el primitivo archivo condal, sólo veintitrés son estrictamente de los condes de Barcelona, uno de los condes de Besalú o Cerdanya, uno del vizconde de Barcelona y uno del vizconde de Gerona. De los veintitrés pergaminos de los condes de Barcelona, dos son falsos, siete originales (de dos de los cuales se conserva copia posterior); cinco son originales dudosos, de uno de los cuales hay copia; otros cinco son copias coetáneas (de estos, a su vez, dos son copias coetáneas sin original; otros dos son copias coetáneas o posteriores sin original, y el último es una copia coetánea interpolada). Finalmente, de cuatro sólo hay la copia posterior. «És clar — concluye Rafael Conde- que la dubtosa originalitat, la presència de còpies coetànies, la coexistencia de originals i còpies posteriors, la conservació de documents només en còpies, etc., tant en el fons del segle X com en els posteriors, són realitats que distorsionen i dificulten l'estudi del fons» ${ }^{8}$.

Sigue Rafael Conde con sus cuentas. Del tiempo de Ramón Borrell nos han llegado ciento diecinueve documentos, de los cuales sólo cinco son condales

${ }^{4}$ Udina Martorell, Federico: El archivo condal de Barcelona en los siglos IX-X. Estudio crítico de sus fondos, Barcelona, Consejo Superior de Investigaciones Científicas, 1951, 570 págs.

${ }^{5}$ Ibídem, p. 8.

${ }^{6}$ Más tarde corroboró esta hipótesis SANTS Gros, Miquel dels: «L'Arxiu del Monestir de Sant Joan de les Abadesses. Notícies històriques y regesta dels documents dels anys 995-1115», en II Col.loqui d'Història del Monaquisme Català, Abadia de Poblet, 1974, vol. II, pp. 87-128.

7 UDINA MARTORELL, Federico: El archivo condal..., p. 12.

8 Conde y Delgado De Molina, Rafael: «Estudi arxivístic», en AA.VV, Els pergamins de l'Arxiu Comtal de Barcelona, de Ramon Borrell a Ramon Berenguer I, Barcelona, Fundación Nogera, 1999, vol. I, p. 47. 
(cuatro ventas y una donación). El resto son documentos particulares, cuya pertenencia e ingreso en un hipotético archivo condal plantea los mismos problemas que ya hemos visto. Tampoco cambia la situación con Berenguer Ramón I. De los ciento veintitrés documentos conservados, los considerados propiamente condales por Próspero de Bofarull en sus inventarios son sólo catorce. De ellos, uno viene de Sant Joan de les Abadesses y otro es aragonés. Entre los doce restantes, predominan los actos privados: dos donaciones, cuatro ventas, una restitución, cuatro impignoraciones. Sólo un documento, dice Conde, puede ser considerado expresión de soberanía: la confirmación de los privilegios de los habitantes de la ciudad y condado de Barcelona, de 8 de enero de 1025, por Berenguer Ramón I9.

Con todos estos reparos, Rafael Conde piensa no obstante que este primitivo archivo condal barcelonés fue el punto de arranque del Archivo Real de Barcelona y del de la Corona de Aragón ${ }^{10}$. Muchos años antes, quien fuera director del ACA, Francisco de Bofarull, quiso remontar sus orígenes a los capitulares Pro Hispanis, de Ludovico Pío de los años 815 y 81611. Para Martínez Ferrando, ello no pasa de ser una vaguedad y, por lo tanto, no puede tomarse en consideración ${ }^{12}$. Tampoco son razones convincentes para Conde, quien, tras rebatir los argumentos de Francisco de Bofarull ${ }^{13}$, vincula el nacimiento del archivo a la acumulación de documentos que va paralela al desarrollo del ejercicio de la soberanía de los condes de Barcelona y de un particular aprecio por la documentación, consecuencia indudable de lo que se ha llamado "pervivencia del visigotismo», entre cuyas realidades está la aportación de pruebas escritas a los juicios ${ }^{14}$. Para nuestro llorado amigo, fue con Ramón Berenguer I cuando el archivo empezó a desarrollarse. La inmensa mayoría de los documentos anteriores a este conde custodiados hoy en el ACA consiste en actos jurídicos entre particulares, relativos a propiedades que se integraron en su momento en el patrimonio condal y real. Hay que esperar al gobierno de Ramón Berenguer I para encontrar un importante conjunto de instrumentos condales sensu estricto, que predominen sobre los actos privados (es decir, donaciones, compra-ventas y similares). Los documentos propiamente condales suben entonces al 41,4\% del total de los conservados, cuando en tiempos de Ramón Borrell y de Berenguer Ramón I el Curvo representaban sólo el 4,2\% y el

\footnotetext{
9 ACA, Real Cancillería, Pergaminos de Berenguer Ramón, núm. 50.

${ }_{10}$ Una historia de los orígenes del ACA, en CONDE Y Delgado DE MolinA, Rafael: Les primeres ordinacions de l'Arxiu Reial de Barcelona. 1384 / Las primeras ordenanzas del Archivo Real de Barcelona. 1384, Madrid, Ministerio de Cultura, 1993, 44 págs.

${ }^{11}$ En una obra que no llegó a ver la luz pero que fue aprovechada por González Hurtebise y de la cual se conserva una parte de las galeradas (BOFARULL, Francisco de: (Historia del Archivo de la Corona de Aragón\}, Incompleta. s.a, s.l., pp. 12-13 y doc. I).

12 Martínez Ferrando, Jesús Ernesto: El Archivo de la Corona de Aragón, Barcelona, 1944, p. 23.

${ }_{13}$ CONDE, Rafael: «Estudi arxivístic...», vol. I, págs. 44 y ss.

${ }^{14}$ CONDE, Rafael: Reyes y archivos...
} 
$12,2 \%$, respectivamente. Por otra parte, en el conjunto de estos pergaminos propiamente condales (por usar los términos de Próspero de Bofarull ) de Ramón Berenguer I predomina ya la documentación «soberana», centrada en dos tipos documentales: la convenientia y el sacramentale, que significan respectivamente, el 22,7 \% y el 50,6\%. Para Rafael Conde, por la tipología de los pergaminos y por la cantidad de ellos conservada, puede hablarse plenamente de un archivo condal a partir de Ramón Berenguer $\mathrm{I}^{15}$.

En efecto, la pervivencia del derecho visigótico en Cataluña mantuvo un sistema judicial en el que la prueba documental era básica para demostrar y reclamar derechos, por lo que interesaba guardar los documentos. Es una de las razones habitualmente esgrimidas para explicar la abundancia de la documentación de época condal. Desde principios del siglo XI, además, proliferan las conveniencias y juramentos que ponen por escrito los acuerdos para vertebrar el territorio y establecer las relaciones de poder y económicas entre el conde y los grandes del país. De hecho, ambos tipos documentales desempeñaron un papel central en la organización de la sociedad catalana hasta fines del siglo XII. En realidad, esta «mutación documental» es un reflejo del cambio institucional y social; es más, forma parte de este cambio ${ }^{16}$. Sin embargo, este proceso, ampliamente estudiado, no prueba por sí sólo la existencia de un archivo condal. Más bien al contrario. Pues de lo dicho hasta aquí resulta claro que se mezclan dos cuestiones distintas: una, es la procedencia y cantidad de la documentación de esa época que existe hoy en el ACA (sea propia de los condes o particular, abundante o escasa), que pudo ser guardada en un monasterio, o en el palacio de los condes, como lo señaló ya Martínez Ferrando ${ }^{17}$. Y otra cuestión es la existencia de un archivo condal. Para avanzar conclusiones firmes que no sean meras suposiciones hay que continuar el camino desbrozado en parte por Udina. Lo que queda por delante es una tarea erudita de alta investigación, larga, ardua y en algunos casos imposible de ejecutar: la de determinar la procedencia y la fecha de ingreso en el ACA de todos y cada uno de los pergaminos de época condal. Sólo después puede valorarse el alcance y contenido de los depósitos documentales del tiempo de los condes de Barcelona. Pero, sin necesidad de abordar esta tarea, lo que resulta incontrovertible es la rotunda afirmación de Martínez Ferrando: «Las escrituras de época condal no contienen la menor alusión a la existencia del Archivo» ${ }^{18}$. Y es verdad, añade con resignación Conde ${ }^{19}$.

15 CONDE, Rafael: «Estudi arxivístic...», vol. I, p. 49.

${ }^{16}$ Es la tesis central de Kosto, Adam J.: Making Agreements in Medieval Catalonia. Power, Order and the Written Word, 1000-1200, Cambridge, Cambridge University Press, 2001, especialmente pp. 268 y ss.

17 Martínez Ferrando, Jesús Ernesto: Archivo de la Corona de Aragón. Guia abreviada. Madrid, 1958, p. 7.

18 Martínez Ferrando, Jesús Ernesto: El Archivo de la Corona de Aragón..., p. 25.

19 CONDE, Rafael: «Estudi arxivístic...», p. 45. 
Claro que lo es. Hasta el día de hoy, nadie ha podido aportar constancia documental ninguna de que en 1137 o antes existiera un archivo condal de Barcelona, como tal institución Si hubiera existido, quizá Ramón Berenguer III no hubiera perdido un pleito en 1113 porque no pudo encontrar ciertos juramentos escritos ${ }^{20}$. Lo que hoy se conserva en el ACA son documentos de época condal, procedentes en algunos casos de las escribanías de los condes de Barcelona, que pasaron por diversas manos o se guardaron en diversos depósitos antes de su ingreso en el Archivo Real de Barcelona muchos años, y aun siglos, más tarde. Otros documentos de esa época ingresaron en el ACA bastante después (como en el caso ya mencionado de Sant Joan de les Abadesses), y unos y otros se mezclaron hasta constituir las colecciones tal como hoy se conocen. Ciertamente, el rigor en la confección de los documentos, su abundancia, los cuidados para su conservación y su reparación atestiguan la importancia que la sociedad catalana concedió a la escritura, como se ha hecho eco Michel Zimmermann en su monumental obra, en la cual, sin embargo, no puede estudiar la existencia de archivos como conjuntos orgánicos de documentación ni como instituciones con personalidad jurídica ${ }^{21}$. Pues una cosa es la elaboración y conservación de documentos y otra es que esos documentos se custodiaran en archivos, y aún otra diferente es que los condes de Barcelona dispusieran de un archivo propio. En cualquier caso, estos depósitos de pergaminos, si los hubo, distaban mucho de constituir un archivo: por lo visto hasta aquí, se limitarían a unas decenas o unos pocos centenares de pergaminos, guardados en sacos o en arcas, que se conservarían dispersos en el palacio condal, en casa de particulares, de oficiales, de monasterios o iglesias, como supuso Martínez Ferrando. Para Aragón, Ángel Canellas aventura, sin fundamentarlo en datos concretos, que tal vez durante algún tiempo las capillas reales creadas por el rey Sancho Ramírez, en especial la de Montearagón, pudieron ser depósitos de documen$\operatorname{tos}^{22}$. También el monasterio de San Juan de la Peña sirvió a estos fines. ${ }^{23}$ Por toda la Europa de los siglos XI y XII, los documentos reales se dejaban depositados de manera dispersa por iglesias y monasterios de especial confianza de los monarcas o según sus personales devociones, sin constituir un depósito central u organizado hasta mucho más tarde. Tampoco la conservación de las escrituras reales era sistemática, ni se hacía con finalidades administrativas ni, mucho menos, historiográficas o de exaltación del poder regio ${ }^{24}$. Sólo se conservaban,

20 Kosto, Adam J.: Making Agreements..., p. 274.

21 Zimmermann, M.: Écrire et lire en Catalogne (IX $X^{e}-X I I^{e}$ siècle), Madrid, Casa de Velázquez, 2003, especialmente vol. I, pp. 61-89.

22 Canellas, Ángel: «La Cancillería real del reino de Aragón (1035-1134)», en Folia Budapestina, Zaragoza, 1983, p. 25.

23 LALiena CorberA, C.: «La memoria real en San Juan de la Peña: poder, carisma y legitimidad en Aragón», en Aragón en la Edad Media, XIX (2006), pp. 309-324.

24 Como en Inglaterra, por ejemplo, caso bien estudiado por CLANCHY, M.T.: From memory to Written Record. England, 1066-1307, Londres, Edward Arnold, 1979. 
de manera anecdótica y muy selectiva, los documentos a los que se atribuía un valor especial para justificar de manera inmediata el dominio del monarca en el trono, es decir, lo que Carlos Laliena considera que eran «las piezas capitales para testimoniar la legitimidad del linaje real y las bases de su autoridad». ${ }^{25}$ Ahora bien, se plantea entonces la cuestión de si puede denominarse «archivo» a uno o varios sacos de pergaminos dispersos y aislados, sólo por el mero hecho de conservarse, con independencia de la autoridad de su propietario o de su organización y naturaleza, considerando el asunto tanto desde el punto de vista del vocabulario histórico utilizado en la Edad Media como desde el aspecto estrictamente jurídico. Por eso, es necesario introducir aquí una serie de precisiones conceptuales.

\section{ALGUNAS PRECISIONES CONCEPTUALES.}

Hoy entendemos por archivo un concepto bastante vago, al menos desde un punto de vista jurídico. Según el Diccionario de uso de María Moliner, es el «lugar en que se guardan documentos», en su primera acepción, y en una segunda, «el conjunto de los documentos custodiados». Esta definición, para el uso habitual, es suficiente, pero no es quizá lo que los hombres de la Edad Media entendían por archivo. Hemos de remontar en el tiempo nuestras pesquisas. Para el Diccionario de Autoridades compuesto por la Real Academia en 1726, archivo es el «lugar público donde se guardan los papeles e instrumentos originales, en que se contienen los derechos del Príncipe y particulares, dándoles mayor fe y autoridad la circunstancia del lugar». Aquí vemos sintetizadas algunas de las caracterizaciones más rigurosamente jurídicas del concepto que venimos tratando, aunque algo degradadas respecto a lo que había sido originariamente.

En sentido estricto, para el pensamiento jurídico medieval, como brillantemente lo ha puesto de relieve Elio Lodolini, un archivo sólo podía ser establecido por quien gozaba del ius archivi, potestad estrechamente vinculada a la soberanía, por lo que en principio sólo correspondía al papa o al emperador, y a los reyes a partir del siglo XIII, cuando se difundió la máxima jurídica de inspiración boloñesa rex superiorem non recognoscens in regno suo est imperator. La concepción del ius archivi como atributo de la soberanía, que tuvo una amplia aceptación en la doctrina durante la Edad Moderna, obedece a que el archivo goza de fe pública que comunica a los documentos que en él se custodian. Y sólo la autoridad soberana, sea el emperador (o el rey, más tarde), sea el pontífice, puede conferir la fe pública, como ocurre en el caso de los notarios ${ }^{26}$. Que

\footnotetext{
${ }^{25}$ LALIENA CORBERA, C.: «La memoria real...», p. 320.

${ }^{26}$ LODOLINI, Elio: Lineamenti di storia dell'Archivistica italiana (Dalle origini alla metà del secolo XX), Roma, 1991, pp. 31-34, 49-56, y 67-75.
} 
el archivo es marca de soberanía y que los documentos emanados de la autoridad regia deben conservarse en su archivo, tanto por razones jurídicas, como por otras de carácter político y aún de índole simplemente pragmática, es algo que no fue sólo una elucubración de juristas, sino que tuvo una aplicación práctica en la Baja Edad Media ${ }^{27}$.

Pero también porque es una consecuencia del proceso de recuperación del Derecho romano, y por tanto, de la vieja definición justinianea del archivo como locus in quo acta publica asservantur, con el frecuente añadido ut fidem faciant, tal como se recoge en diversas disposiciones del Corpus Iuris Civilis. Esta definición, que se encuentra en algunos juristas desde fines del siglo XII, obedece a una rigurosa concepción jurídica del documento, y fue ampliamente recogida por los tratadistas y comentaristas del derecho de los siglos XIII y XIV ${ }^{28}$. La palabra archium (derivada del griego archeion, y ésta a su vez de arché, "mando», «magistratura») se encuentra ya en la primera mitad del s. I d.C., en Pomponio Mela, El emperador Marco Aurelio (161-180) la emplea en una carta dirigida a su maestro Fontone a propósito de la conservación de los testamentos, en una lectura dudosa, junto a la voz «arca»: olim testamenta ex deorum munitissimis aedibus proferebantur, aut tabulariis aut (ar)cis aut archis aut opisthodomis ${ }^{29}$. Veremos que esta vacilación se presenta también en la documentación de la Cancillería real aragonesa. Evoluciona hacia la forma archivum desde fines del s. II d.C., usada generalmente en plural. En Tertuliano designa el atrio del templo donde se reunían los sacerdotes, pero este autor también la utiliza como sinónimo de armaria y tabularia ${ }^{30}$. Con un significado jurídico más preciso para designar el lugar en el que se conservan los documentos a fin de que les sea conferida fe pública, figura bajo la forma archium en el Corpus Iuris Civilis en una disposición atribuida a Ulpiano, quizás interpolada ${ }^{31}$. La fe pública le viene conferida al archivo, pues, por su pura definición jurídica, y tiene su praxis en la llamada probatio per archivum (de tanta raigambre en el mundo medieval y de la Edad Moderna) $)^{32}$, que garantiza la autenticidad del documento y la plenitud de sus efectos jurídicos, en razón de su custodia ininterrumpida en el archivo, entre otras causas ${ }^{33}$.

27 Hemos tratado de demostrarlo en LóPEz Rodríguez, Carlos: «El Archivo Real de Barcelona en tiempos de Fernando I de Antequera (1412-1416)», en Signo. Revista de la cultura escrita, 12 (2003), pp. 31-60.

${ }^{28}$ LODOLINI, Elio: Lineamenti..., pp. 20-47.

${ }^{29}$ LODOLINI, Elio: Lineamenti..., p. 24, n. 28.

${ }^{30}$ DU CANGE: Glossarium ad scriptores mediae et infimae latinitatis, s. v.

${ }^{31}$ LODOLINI, Elio: Lineamenti..., pp. 24-25.

32 SANDRI, Leopoldo: «La storia degli archivi», en Archivum, XVIII (1968), pp. 101-113.

33 Aunque se trate de un principio hoy inexplicablemente relegado, la «custodia ininterumpida» de un documento en el archivo (concebido eso sí, con los restrictivos requisitos de los que en este trabajo se parte) es garantía de su autenticidad, y para ciertos autores de la moderna doctrina archivística, como $\mathrm{H}$. Jenkinson, es lo que marca la diferencia entre el documento que es un documento de archivo y el que no lo es (Cfr. Lodolini, , Elio: Archivistica. Principi e problemi, Milán, 1987, p. 121). 
La concepción de archivo como locus in quo acta publica asservantur (ut fidem faciant) se encuentra ya en el comentario del Piacentino (circa 1135-1192) al Corpus iuris civilis y a partir de entonces en otros muchos famosos glosistas, como Accursio (1184-1263), Cino da Pistoia (1270-1336/7), Alberico da Rosate (fines del siglo XIII-1354) o Baldo degli Ubaldi (1327-1400) cuando comentan el título relativo a la fe de los instrumentos. Nos interesa resaltar especialmente dos referencias, cuya trascendencia veremos más tarde. Una, el comentario de Tancredo de Bologna (penúltimo decenio del siglo XII- antes del 1236), que afirma: instrumentorum duae sunt species: aliud est publicum, aliud est privatum (...) sexto loco dicitur publicum quod de archivio seu armario publico producitur, liber scilicet rationum; et ei creditur, si habet publicum testimonium, scilicet, quod iudex confiteatur illum de archivo publico esse productum (... $)^{34}$. Y la segunda, contenida en el Liber constitutionum Regni Siciliae, promulgado en 1231 y considerado el más grande monumento legislativo laico de la Europa medieval, en el cual la conservación de determinados documentos in archivio nostrae Curiae es dispuesta por Federico II como prueba eficaz ${ }^{35}$.

La historia de los archivos no puede apartarse de la historia general, en especial de la cultural y la política o administrativa, porque el nacimiento y desarrollo de los grandes archivos están indisolublemente ligados al largo proceso de estatalización (es decir, del surgimiento y consolidación del Estado como forma política) de las sociedades europeas, y estrechamente vinculados a la formación y funcionamiento de las monarquías absolutas que se inició a fines de la Edad Media ${ }^{36}$. El surgimiento del concepto de archivo como lugar público en el que se conservan y depositan documentos para causar fe pública está estrechamente ligado al desarrollo de la práctica notarial, desde un punto de visto técnico, y al fortalecimiento de los poderes públicos, desde un punto de vista político. Desde esta perspectiva histórico-jurídica, los archivos no son meros almacenes de documentos al servicio de los investigadores contemporáneos, sino unos instrumentos básicos del ejercicio concreto del Poder en sus sucesivas fases históricas, cuya importancia crece a medida que la maquinaria burocrática del incipiente Estado es más reducida y los elementos coactivos a disposición de los soberanos son más constreñidos. A este respecto, el caso del ACA es modélico, por cuanto plasma de una manera muy temprana y claramente visible este proceso.

Como vemos, los comentaristas introducen en la doctrina el concepto de archivo, ligado al de la fe pública y al de soberanía, desde fines del siglo XII y,

${ }^{34}$ Ibídem, p. 28.

35 Ibídem, p. 28.

${ }_{36}$ Véanse a este respecto las interesantísimas consideraciones -referidas fundamentalmente al Archivo de Simancas- realizadas por José Luis RoDRíGUEZ DE DIEGO en el estudio introductorio a la edición de la Instrucción para el gobierno del archivo de Simancas (1588), Madrid, Ministerio de Cultura,1989, 115 págs.; y su trabajo «Archivos del poder, archivos de la Administración, archivos de la Historia (s. XVI-XVII)», en Historia de los archivos y de la Archivística en España, coordinado por J. J. Generelo y A. Moreno López, Valladolid, 1998, pp. 29-42. 
más clara y extensamente, desde las primeras décadas del siglo XIII. Pero hasta que la recuperación del Derecho romano no culminó su obra con plenitud, la autoridad del rey dependió más de sus armas y sus castillos que de sus archivos: como dice M.T. Clanchy, para los negocios del día a día, el gobierno del rey (o del conde) necesitaba documentos, pero no necesariamente requería de documentos históricos ${ }^{37}$. Todavía a mediados del siglo XIII, la carga de conservar los documentos reales recaía principalmente en el beneficiario de la voluntad regia, lo que trasluce una renuncia del monarca a construir su propia memoria dinástica y a custodiar los instrumentos jurídicos y administrativos que garantizan el ejercicio de su poder, cuyo enorme potencial aún no había sido valorado en su justa medida, como lo haría Jaime II a partir de 1291. En 1258, Jaime I ordenó que la ciudad de Valencia conservase los privilegios reales en una caja fuerte, orden que presumiblemente recibieron otras ciudades ${ }^{38}$. Fue esta despreocupación inicial de la Cancillería regia (y antes de las escribanías condales), común al medio cultural y jurídico coetáneo, lo que explica la falta de interés por conservar de manera sistemática la documentación emitida o recibida.

Esta son algunas de las razones por las que, desde el punto de vista de la teoría jurídica y política, no podía haber un archivo condal. Por eso, tampoco hay la más mínima constancia de la existencia de un archivo real aragonés de la dinastía de los Ramírez ${ }^{39}$. Ni en Aragón ni en Cataluña. Y, precisamente por eso, sorprende la mención muy temprana, en 1180, que casi puede considerarse una anomalía desde un punto de vista cronológico, a un archivo de los reyes aragoneses tras la unión dinástica con Cataluña. Toca ahora analizar el proceso de implantación de la voz «archivo» con su significado plenamente jurídico en la Cancillería aragonesa.

\section{IMPLANTACIÓN DE LA VOZ «ARCHIVO» EN LA CANCILLERÍA REGIA ARAGO- NESA.}

Esta primera mención a un archivo real en los territorios de la Corona de Aragón dada bajo el reinado de Alfonso el Casto, primer rey de la unión, ha sido analizada por Conde, cuyos razonamientos sintetizamos ${ }^{40}$. En 1180, la

37 Clanchy, M.T.: From memory to Written Record..., pp. 146-147.

38 BURNS, Robert Ignatius: Diplomatarium of the crusader Kingdomof Valencia, Princeton, 1985, vol. I , p. 20, n 12, con referencia a ACA, Real Cancillería, reg. 9, fol. 25.

39 Canellas, A..: «La Cancillería real...», pp. 23-46. Para Conde, el hecho de que no aparezcan cartas partidas en la documentación de los Ramírez indica que de los documentos no quedaba un ejemplar para el rey y que, por tanto, no pudo surgir un archivo (CONDE, Rafael: Reyes $y$ archivos...)

${ }^{40}$ CONDE, Rafael: «Estudi arxivístic...», pp. 20-22. El documento en ACA, Real Cancillería, Pergaminos de Alfonso I, núm. 302. Lo menciona también Kosto, Adam J.: Making Agreements..., p. 246. 
curia real estaba reunida en Tarragona con motivo del concilio celebrado por el arzobispo. Entre otros temas se discutió el carácter alodial o feudal de los castillos de Lluçà y de Merlès, que tenía Pere de Lluçà. Ante la corte, actuando como jueces Bernat d'Anglesola, Guerau de Jorba, Berenguer de Boixadors, el maestro Opizò, Pere de Rebollet y Berenguer de Calonge, comparece Lluçà y afirma que el castillo es alodial y que nunca ni su padre ni su abuelo habían rendido la potestad del castillo a los antecesores del rey. Aporta como prueba el testamento de su padre, que contiene la donación en herencia de los castillos como alodio. El rey, a su vez, sostiene el carácter feudal del castillo y aporta cuatro documentos y dos testimonios, que se conservan aún en original en el ACA. El primero de ellos es quodam sacramentale in quo Guissaldus dominus de Luzano Raimundo comiti Barchinone de tota terra sua fidelitatem iuraverat et dare potestatem de ipsis castris de Luzano et de Merles. Pere de Lluçà intenta desautorizarlo aduciendo el hecho de carecer de fecha y de firma, razón por la cual, de acuerdo con la ley de Chindasvinto Quales debeant scripturae valere, recogida en el Liber Iudicum ${ }^{41}$ no tiene valor probatorio en juicio. Responde el rey que es cierto que carece de estas formalidades, pero que talem tunc fuisse consuetudinem terre faciendi buiusmodi sacramentalia. Añade que, para probarlo, inducebat alia similia sacramentalia de suo archivo producta.

Es la primera vez que aparece citado en un instrumento un depósito documental. Para Rafael Conde, no puede tratarse sino del viejo archivo condal, ubicado tal vez en el antiguo palacio condal o tal vez en algún monasterio próximo. Esta es, sin embargo, una suposición no demostrada. La pieza merece un análisis más pormenorizado, que reservamos para otro momento. Por ahora, baste destacar que la expresión con la que se refiere al archivo recuerda demasiado a las fórmulas utilizadas por los comentaristas del siglo XIII, por ejemplo la de Tancredo de Bologna; y que el procedimiento de prueba por medio del archivo es similar al establecido en las leyes sicilianas de Federico II. Por otro lado, nos enfrentamos al significado de las propias palabras y a su evolución semántica. Algunos autores, como Conde y Adam J. Kosto, piensan que el crecimiento de la burocracia y la multiplicación de los documentos durante el siglo XII necesitaron de avances en la práctica archivística, que tuvo su eclosión bajo Alfonso II y de la cual este documento constituye una demostración. ${ }^{42}$ Sin embargo, sorprende que esta primera mención no recoja un significado antiguo y puramente etimológico de la palabra archivum, como hubiera sido previsible, referida al arca o armario donde se guardan unas escrituras, sino que aparezca ya plenamente formada, sin antecedentes documentados, con un significado implícito muy moderno para la época, aunque tomado de la

41 Scripturae quae diem et annum habuerint evidenter expressum, atque secundum legis ordinem conscriptae noscuntur, seu conditoris vel testium fuerint signis aut subscritionibus roboratae, omnem babeant stabilem firmitatem.

${ }^{42}$ Kosto, Adam J.: Making Agreements..., p. 274. 
literatura jurídica romanista, como lugar privilegiado por la soberanía regia que comunica fe pública al instrumento custodiado en él.

Rafael Conde, como otros que le precedieron al tratar la historia del ACA, pasa a examinar tras esta mención la formación del cartulario real conocido Liber Feudorum Maior ${ }^{43}$. Por eso incluye su famosísimo prólogo como una de las piezas documentales de la historia del ACA. Cierto es que allí el deán Ramón de Caldes, encargado de la recopilación y sistematización del Liber, declara que su misión consistía en que omnia instrumenta propria et inter vos [el rey] vestrosque antecessores ac homines vestros confecta et in ordinatione confusa, sub uno redigerentur volumine, tum propter subiectorum, scilicet utilitatem ut, his instrumentis ad memoriam revocatis, unusquisque ius suum sortiatur, tum propter eternam magnarum rerum memoriam, ne inter vos et homines vestros, forte oblivionis occasione, aliqua questio vel discordia possit oriri $(\ldots)^{44}$. Ahora bien, en contra de lo que interpretan Conde y otros, en este prólogo no se menciona ningún archivo sino sólo una documentación que, eso sí, se dice que se encontraba in ordinacione confusa. Nada sabemos de la confusión a la que se refiere el autor del prólogo. Ni siquiera si con ello quiere decir que todos los documentos se encontraban en un único lugar, desordenados, o si tuvo que recorrer varios lugares para copiarlos. Claro que todo ello no es una prueba ni a favor ni en contra de la existencia de un archivo real a fines del siglo XII. Por esta razón, el Liber Feudorum Maior, que ofrece todavía hoy muchos problemas dignos de estudio, no contiene en sí mismo datos relevantes para una historia documentada del ACA como depósito. En el mejor de los casos, atestiguaría que había unos pergaminos que, ubicados en uno o varios lugares indeterminados a disposición del monarca, con motivo de la compilación del Liber — según demuestra Rafael Conde de una manera muy documentada, erudita y sugestiva - se ordenaron y clasificaron en sacos de contenido probablemente homogéneos antes de ser copiados.

Hasta aquí, se nos han planteado varias dudas, hemos tropezado con algunas suposiciones, y se ha asentado sólo una certeza: la mención a un archivo real, por lo que se sabe hasta ahora, sea sospechosa o no, es posterior a la unión dinástica de Aragón y Cataluña. No la hay de época condal por una imposibilidad no sólo material, sino también conceptual, pues el archivo fue considerado una marca de soberanía y con validez jurídica sólo a partir de fines del siglo XII, como hemos visto. Por otro lado, desde 1137, momento de la unión dinástica, hasta mediados del siglo XIII, como veremos, no hay más mención a un archivo real que la de 1180 . Pero descendamos a los detalles.

43 CONDE, Rafael: Reyes y archivos... Al Liber feudorum mayor le han dado gran importancia, como es natural, quienes han tratado la relación entre escritura y poder, tanto Adam J. KosTO, (Making Agreements..., pp. 281-285) como M. ZimmermanN, M. (Écrire et lire en Catalogne..., vol. I, pp. 58-60), entre otros muchos estudiosos.

${ }_{44}$ MiQuel Rosell, Francisco: Liber Feudorum Maior. Cartulario real que se conserva en el Archivo de la Corona de Aragón. Barcelona, 1945, vol. I, pp. 1-2. 
Si partimos de la reconstrucción del Liber Feudorum Maior realizada por Miquel Rosell, que no obstante sus méritos ha recibido críticas $^{45}$, este cartulario real estaría formado por 902 documentos. De estos, sólo se conserva en el ACA el original de 517 pergaminos ${ }^{46}$. De sus estudios, Conde concluye que los sacos en los que se organizaron los documentos copiados en el Liber no contenían gran cantidad de documentos; en algunos casos en torno a una docena ${ }^{47}$. Pero él mismo transcribe una documento de abril de 1256, en el que consta que los representantes del rey sacaron 94 documentos de Sijena en un único saco ${ }^{48}$. Así pues, con independencia de los problemas de datación del Liber Feudorum Maior, y en la situación más favorable (esto es, que todos los pergaminos copiados en él estuvieran realmente en la época a la que generalmente se atribuye su formación, bajo el reinado de Alfonso II, en un único depósito y no dispersos en varios), el conjunto de documentos que integra la actual versión del Liber podía contenerse en unos 10 a 75 sacos. Siendo tan poca cosa, podía guardarse en un arca o arcón, en el propio palacio real o en algún monasterio próximo, como sugirió Martínez Ferrando ${ }^{49}$. Pero, como ya hemos indicado, esta colección de pergaminos, de existir, no constituía propiamente todavía un archivo, aunque el propio Liber quiere comunicar una fe pública, no muy claramente definida por otro lado, a los documentos copiados en él.

¿Cuándo aparece en la documentación real aragonesa la voz archivo de una manera habitual y con qué significado lo hace? Como veremos más adelante, a partir de 1255 comienzan las menciones ya muy numerosas a un depósito real de documentos en el monasterio de Sijena, en Aragón, pero sin utilizar el término «archivo». En efecto, las noticias sobre este depósito se refieren de modo genérico a cartas e instrumentos que se custodian en el monasterio. Ocasionalmente, se refieren al archa domini regis que existe en este monasterio en el que se guardan los documentos, como ocurre en 1255,1259 y $1260^{50}$. En mayo de 1269, Jaime I escribe a la priora de Sijena ordenándole entregar a su escribano Miguel Violeta las llaves del arca que contiene los documentos reales (clavem arche nostre ubi sunt instrumenta nostra) y que le permita retirar los que tocan al reino de Navarra ${ }^{51}$. En septiembre de ese mismo año, Salvador, canónigo de Barcelona, retira por orden del rey treinta y un instrumenta y tres escrituras en papel sobre los negocios de Montpellier, Rosellón y Mallorca después

${ }^{45}$ RuIZ-Domènec, José Enrique: A propósito de Alfonso, rey de Aragón, conde de Barcelona y marqués de Provenza. Discurso leído el día 29 de febrero de 1996 en el acto de recepción pública de --- en la Real Academia de Buenas Letras de Barcelona. Barcelona, 1996, pp. 118-119.

46 CONDE, Rafael: «Estudi arxivístic...», pp. 45-46.

47 CONDE, Rafael: Reyes y archivos...

48 CONDE, Rafael: El Archivo de Sijena...

49 Martínez Ferrando, Jesús Ernesto: El Archivo de la Corona de Aragón..., p. 25.

50 CONDE, Rafael: Reyes y archivos..., doc. 4.

51 CONDE, Rafael: Reyes y archivos..., doc. 11. 
de examinar todo lo que había in scriniis et archivis de ese monasterio ${ }^{52}$. En julio de 1272, Jaime I extiende una credencial ante la priora de Sijena a favor del clérigo real Fortuny para que le facilite el acceso a omnia instrumenta sive privilegia ac eciam registrum que et quod sunt in archis cartarum nostrarum in monasterio vestro Sexene super facto Montispesulani aliqua racione vel causa53. En 1274 se denomina cartolaria in quibus sunt (...) instrumenta ${ }^{54}$.

En Sijena, los textos hablan de archa nostra, de cartolaria, de archis y también de scrinia et archiva. Siempre en plural, como hemos visto, según el uso latino clásico que curiosamente se ha perpetuado en el habla vulgar de nuestros días y se ha mantenido en otras lenguas modernas, por ejemplo en francés e inglés. Vemos, pues, que en estos documentos la voz "archivo», cuando se emplea, que es en contadas ocasiones, parece corresponderse con un supuesto significado etimológico más estricto, como arcas en la que se guardan documentos, que, en Sijena, entre 1255 y mayo de 1269 es una sola, pero desde septiembre de 1269 son varias. Y aunque la voz «arca» es ampliamente utilizada en el mundo religioso y eclesiástico con un valor simbólico, no parece que sea éste el uso con el que se emplea en la documentación que comentamos. En los contextos en que aparece, se limita a designar el mueble en el que se guardan los documentos.

La mención a un archivo por el rey, con esta denominación y como depósito de documentos, no se ha empleado desde 1180 y no vuelve a repetirse hasta otro documento de 4 de abril de 1264 . Se trata de unas instrucciones dadas a Bernat de Vic, juez delegado para aclarar las enajenaciones del patrimonio real en la Cerdaña, el Conflent, el Ripollès, veguería de Camprodon y valle de Prades, de 4 de mayo de $1264^{55}$. En ellas, el rey ordena al juez de curia Bernat de Vic tomar por verdaderas las noticias sacadas de los registros y cabreos de nostro [del rey] archivo publico, a los cuales de debe dar fidem plenam. Esta referencia a un «archivo público» que presta fe a los documentos que contiene se aproxima mucho a la mención de 1180, hasta el punto de que parece haber bebido de una misma fuente, y contrasta con el uso que se hace en otra documentación coetánea.

Rafael Conde no aventura dónde pudo ubicarse este «archivo público». Parece identificarlo con el supuesto depósito existente en el propio palacio real donde se guardarían los documentos más preciados. Según Hurtebise el Liber Feudorum maior se conservó siempre allis ${ }^{56}$. Pero de este depósito no tenemos noticia hasta una orden de 1286 dada por Alfonso el Liberal a Pere de Sant Climent para localizar dos documentos que sus embajadores debían llevar a Roma, de los cuales se tomaría traslado visado por el arzobispo de Tarragona y

52 CONDE, Rafael: Reyes y archivos..., doc. 14.

53 CONDE,, Rafael: Reyes y archivos..., doc. 16.

${ }^{54}$ CONDE, Rafael: Reyes y archivos..., doc. 18.

55 CONDE, Rafael: Reyes y archivos..., doc. 9.

56 GONZÁlez HurTebise, Eduardo: Guía..., p. 7. 
cuyos originales debían devolverse a su lugar ${ }^{57}$. Estos documentos, que eran el testamento de Pedro el Grande y la donación en vida de sus reinos a su hijo, se encontraban in domo repositi palacii nostri en una caxia blancha en cuyo interior había quedam candelaria, cuyas llaves, de la caja y de la candelaria, tenía el rey y las envía. Una vez sacados los traslados, deberá devolver las llaves al reboster Pere de Tàrrega.

Sin embargo, no se ha encontrado constancia documental que vincule esta caja blanca existente el palacio real en 1286 con el archivo real de 1180 , con los documentos del Liber Feudorum Maior — considerado anterior a 1192-o con el archivo público de 1264. Más bien, puede argumentarse lo contrario. Si hubiera existido un archivo real u otro depósito similar en Barcelona, en el palacio real de esta ciudad o en otro monasterio, las menciones hubieran sido más numerosas, como las que se refieren al depósito de Sijena, muy abundantes y tempranas, como veremos. Y si hemos de creer al documento de 1180, de haberse podido presentar como prueba en los juicios documentos conservados en un archivo real, causando fe pública, hubieran menudeado las referencias a su uso y consulta. Lo sorprendente, pues, de la temprana mención de 1180 es la ausencia de noticias sobre este viejo archivo condal o real, sobre todo desde mediados del reinado de Jaime I, cuando abundan sobre Sijena, y posteriormente hasta la fundación del Archivo Real en 1318, y aún después, sin que se encuentren las referidas a ese depósito antiquísimo ubicado en el Palacio Real.

De 1303 es una orden de Jaime II dada al prior de los predicadores y al comendador de la casa de San Juan de Jerusalén, de Barcelona, para colaborar con Mateu Botella en la búsqueda y traslado de quorumdam instrumentorum continencium pacta que inter illustrem Alfonsum, regem Castelle, et nos inita sunt queque reposita sunt in scriniis sive caxiis nostris quas habemus in domo dicti Hospitalis ${ }^{58}$. En el comienzo del reinado de Jaime II, continúa pues el uso tradicional (caja, arca, armario, scrinium) para designar estos depósitos de documentos reales en casas ajenas a la Corona, aunque de su especial confianza. El uso del término archivo en una acepción más próxima a su definición jurídica no arraiga de manera sólida en la Cancillería aragonesa todavía a principios del siglo XIV, aunque se documenta esporádicamente, incluso cuando las noticias sobre la custodia de documentación son ya relativamente abundantes. En su historia del ACA, Francisco de Bofarull copia una carta del rey Jaime II dirigida a Roberto, primogénito del rey de Sicilia, datada en Zaragoza el 1 de julio de 1304, sobre un rescripto acerca de la concesión del ducado de Calabria, en la cual le comunica que denique vos scire volumus rescriptum pretactum fore in archivo nostro repositum ac utiliter conservatum ${ }^{59}$. Nos parece que Martínez Ferrando hace una

57 CONDE, Rafael: Reyes y archivos..., doc. 22.

58 ACA. Real Cancillería, reg. 130, fols. 177v-178v.

59 Bofarull, Francisco de: (Historia...), doc. XXII, sin que se dé la signatura ni lo hayamos podido localizar. 
interpretación forzada de este documento al afirmar que «cuando el Monarca alude en sus despachos al Archivum nostrum se refiere al conjunto de la documentación real dispersa por distintos monasterios, principalmente pertenecientes a la Orden de San Juan de Jerusalén, tanto dentro como fuera de la ciudad de Barcelona» ${ }^{60}$. No es ese el sentido con el que se utiliza en las fuentes de la época. Lo habitual sigue siendo referirse a los contenedores de los documentos depositados en un determinado lugar: in armario suo [del rey] quod est in domo Hospitalis Iherosolimitani Barchinone ubi registra regia reposita sunt, según la expresión del escribano real Mateu Botella ${ }^{61}$, o in caxiis ipsius domini regis que sunt in domo Hospitalis Barchinone ${ }^{62}$, según otro escribano real, Pere de Soler. Ambas referencias son de mayo de 1306. En otra carta sin fecha (que bien puede ser de 1307 o de 1312), el mismo Pere de Soler busca por orden del rey una carta en las caixes vostres qui són a l'Espital en Barchinona ${ }^{63}$. En enero de 1308, Jaime II reconoce haber recibido de la priora de Sijena quamdam archam et quamdam caxiam in quibus erant instrumenta plurima et alie scripture ${ }^{64}$.

Pero unos meses más tarde, en agosto de este mismo año de 1308, se saca el traslado de un documento asentado en un registro que se encuentra in archivo regio in domo Hospitalis Sancti Johannis Hierosolimitani Barchinone ${ }^{65}$. Esta expresión se repite en septiembre de 1312, con motivo de sacarse unas copias certificadas de registra regia in archivo regio posito in domo Hospitalis Sancti Iobannis Iherosolimitani ${ }^{66}$. En otra relación de documentos existentes en una caja depositada en la casa de San Juan de Jerusalén de Barcelona, remitida a Lérida para su estudio, sin fecha pero probablemente, por la materia que se trata, también de 1312, se menciona la caxia illa que erat in archivo domini regis quod est in civitate Barchinona, apud Hospitale Sancti Johannis Jherosolimitani in qua erant reposite et conservate scripture facientes pro valle Aranni ${ }^{67}$. Estas tres menciones a un archivo del rey en la casa del Hospital en Barcelona parece que deben entenderse como un sinónimo del armario al cual se refería Botella en 1306, esto es, como designación del mueble en el que hubieran podido colocarse las antiguas cajas o arcas que existían en el Hospital más las que se recibieron de Sijena, sin que todavía tenga un valor plenamente jurídico, tal como mucho antes lo habían usado Tertuliano o Marco Aurelio, pero, a diferencia del pasado, ahora en singular, uso que se acabará consolidando. Ya hemos visto que los juristas de principios del siglo XIII, como Tancredo de Bolonia, habían utilizado también

\footnotetext{
60 Martínez Ferrando, Jesús Ernesto: El Archivo de la Corona de Aragón..., p. 35.

61 CONDE, Rafael: Reyes y archivos..., doc. 24.

62 CONDE, Rafael: Reyes y archivos..., doc. 25.

63 Bofarull, Francisco de: (Historia...), doc. XX.

64 CONDE, Rafael: Reyes y archivos..., doc. 30.

65 Bofarull, Francisco de: (Historia...), doc. XXI, referido a ACA, Real Cancillería, Pergaminos de Pedro II, núm. 170.

66 ACA, Real Cancillería, Pergaminos, Pedro el Grande, núm. 198.

${ }^{67}$ Bofarull, Francisco de: (Historia...), doc. XIV.
} 
las voces archivo y armario como sinónimos. Y veremos en seguida que las fechas de 1307-1308 tienen su importancia histórica y archivística. Es decir, el archivo que el rey tiene en la casa del Hospital de Barcelona no es todavía el lugar privilegiado al que se refieren los comentaristas, sino un simple armario propiedad del monarca que contiene varias cajas y arcas con sus documentos y que confía a una institución religiosa de su especial confianza, como tendremos ocasión de comprobar en breve.

Tras estas vacilaciones, la voz «archivo» tarda aún en consolidarse en el vocabulario de la Cancillería regia, a juzgar por los materiales de la espléndida colección documental recopilada por Rafael Conde. Ni siquiera se menciona en el albarán definitorio de los gastos de construcción de las estancias para destinarla a archivo de 1319, que se tiene por acta fundacional del Archivo Real, y que examinaremos más tarde. Tampoco en la orden dada en 1332 por Alfonso IV el Benigno para que también se construyeran estancias para archivo del recién ganado reino de Cerdeña, como se puede comprobar: Nos, Alfonsus, etc. Inter alia que circa bonum et prosperum statum regni nostri Sardinie et Corsice ad que continuis vigilamus aspectibus nostre curie neccessario novimus occurrenda convenit quod in Castro nostro Callari fiat quedam domus de volta cum armariis et scriniis in qua omnia compota officialium nostrorum insule Sardinie, et aliorum qui pro nobis in eadem insula aliquod procurarunt seu amministraverunt ac de cetero pro parte nostre curie procurabunt, et eciam omnia registra gubernatorum dicte insule, necnon omnia instrumenta pro curia nostra faciencia reponantur inibi conservanda ${ }^{68}$. Siguen en uso todavía términos como armarios y scrinia (palabra con la que se designan las cajas que sirven para guardar cartas, libros o papeles.) Si no se utiliza con un valor preciso jurídico en la Cancillería, sí se emplea en otros ámbitos de la administración real, aunque con significado genérico pero más próximo al que nos interesa. Por ejemplo, en 1327, se asienta en los libros de cuentas presentados al maestre racional el pago hecho a Julià Despujol por la copia de las cuentas de la camarlenguía de Iglesias que quedan en el archivo de Cagliari (textualmente, arxiu de Castell de Càller ${ }^{69}$.) Es la mención en catalán más antigua que tenemos por ahora procedente de la Cancillería regia. Desde la tercera década del siglo XIV, las referencias al Archivo Real de Barcelona, bajo esta u otra fórmula similar (artxivo Palacii Regii Barchinone, en 1332; in archivo nostro regio Barchino$n e$, en 1346), bien en latín, bien en romance, son habituales. En castellano, la introducción de la palabra «archivo» parece incluso más tardía aún, según piensa Corominas en su Diccionario crítico-etimológico castellano e bispánico. De la obra de Alonso Fernández Palencia, Universal Vocabulario en latín y en romance (Sevilla, 1490), deduce que no era conocida en castellano, "pues solo da una descripción en romance de lo que en latín significa el lat. archiva». Comproba-

68 CONDE, Rafael: Reyes y archivos..., doc. 260, con referencia a ACA, Real Cancillería, Registros, núm. 515, f. 2v-3r. Publicado por CONDE, Rafael: «Los archivos reales o la memoria del poder», en Actas del XV Congreso de Historia de la Corona de Aragón, Zaragoza, 1996, tomo I, p. 139, doc. IV.

69 CONDE, Rafael: Reyes y archivos..., doc. 259. 
mos, pues, que la voz «archivo» se implanta en la Cancillería real aragonesa mediante un proceso largo que se inicia a principios del siglo XIV, cuando en determinados medios burocráticos se acude al uso de este vocablo ya utilizado a fines del siglo XIII con un alcance semántico más limitado, y que sólo adquiere su significado preciso desde un punto de vista léxico y jurídico muy entrado el Trescientos.

\section{El DePósito de DOCumentos De JAime I EN EL MONASTERio De SiJENA.}

Realizada esta digresión histórica sobre la implantación de la palabra «archivo» en la Cancillería aragonesa y la evolución de su contenido semántico, podremos valorar más ponderadamente lo que Rafael Conde llamó «archivo real de Sijena», que estudió magistralmente en su monumental trabajo, desde el punto de vista histórico y archivístico, ya citado, que permanece inédito y que esperemos que aparezca publicado próximamente. Le seguiremos en su análisis, con la sola precisión de que el término "archivo» no se emplea en ninguno de los documentos relativos a este depósito documental, salvo el que ya hemos traído a colación de 1264, con razones de importancia histórica, jurídica y diplomática, como trataremos de demostrar; y en 1269 , pero como sinónimo de la palabra «arca». Resaltemos que, dejando a un lado la mención del año 1180, las referencias al depósito de documentos del rey en el monasterio de Sijena son las más antiguas que se han encontrado relativas a un posible «archivo real» de Aragón o Cataluña. Veamos un breve resumen del estudio de Conde.

Durante varias décadas del siglo XIII el monasterio aragonés sanjuanista de Sijena fue «archivo real». Conde califica al depósito de documentos que allí se hizo de «archivo de Jaime I». Es él quien lo crea, quien lo usa y quien busca y remite documentos. Creado en fecha desconocida por Jaime I, disponemos de información sobre este depósito desde 1255. Conde explica los motivos que llevaron al Conquistador a elegir este monasterio como depósito de documentos. El monasterio de religiosas sanjuanistas de Santa María de Sijena estuvo fuertemente vinculado a la casa real. Fue fundado por la reina Sancha de Castilla, esposa de Alfonso el Trovador, en marzo de 1188, añadiéndolo o adosándolo al de frailes de esa Orden que ya existía en dicho lugar desde tiempos de Ramón Berenguer IV. La regla fue redactada por el obispo de Huesca a petición de Doña Sancha, y aprobada por el Gran Maestre de la Orden el 6 de octubre de 1188. Recibió importantes donaciones y privilegios de los reyes, singularmente en el siglo XIII. Fue también panteón real. Allí estuvieron enterrados su fundadora, Pedro el Católico con parte de los nobles fallecidos en el desastre de Muret, y sus hermanas $\mathrm{D}^{\mathrm{a}}$ Leonor y $\mathrm{D}^{\mathrm{a}}$ Dulce. Jaime I tuvo una especial devoción al monasterio de Sijena, hasta el punto de tomar la decisión de hacerse enterrar allí. La relación del Conquistador con Sijena fue más intensa bajo el priorato de $\mathrm{D}^{\mathrm{a}}$ Sancha Jiménez de Urrea (1226-1237.) Fue entonces cuando supone Conde que pudo crearse el depósito real de documentos. 
Conde apunta que tal vez pudo influir también en la creación de este depósito documental real el hecho de que, ya en 1217, hubieran sido depositados documentos privados de la hermana del rey Pedro II, Constanza de Aragón (esposa en segundas nupcias del emperador Federico II y que había estado en el monasterio por disposición de su padre Alfonso) y otras cartas dotalicias. Y no sólo estos. Otros documentos de particulares fueron depositados en este monasterio entre 1202 y 1224, y en Sijena se custodiaban, para más señas, las insignias de coronación de Pedro el Católico.

Recuerda también Conde la posición central del monasterio en los dominios de Jaime I. La itinerancia de su corte le llevó a situar la documentación en un lugar lo más central posible para facilitar el acceso a su contenido. Sijena, como lo recuerda Ubieto, «era punto obligado de paso en los caminos que llevan desde Huesca o Barbastro al Ebro, a Fraga y a Lérida, estando equidistante de Zaragoza, Huesca, Barbastro, Lérida, y de los valles de los ríos Aguas, Martín, Guadalope y Matarraña» ${ }^{70}$. En resumen, Conde piensa que, dado el continuo movimiento de Jaime I por sus territorios; dado el carácter de Lérida como una casi capital; dadas las comunicaciones entre este centro de poder y Sijena; y dado el carácter de sagrado de un monasterio, lo que daba además garantías de seguridad y conservación, Jaime I decidió crear, para tener a mano fácilmente los documentos, un archivo real en el monasterio de Sijena.

Las noticias que de los documentos allí depositados se tienen a través de las relaciones de ingreso, la salida de documentos o, en ocasiones, de copia, perfilan el de Sijena como un depósito un tanto polivalente, si bien dominan de forma absoluta los documentos relativos a las relaciones con los otros reinos hispánicos, Castilla y Navarra, a la conquista de Valencia, a la herencia de su hijo Jaime, etc. Como responsable del depósito, estaba la priora. A ella se dirigían las cartas credenciales de quienes acudían al monasterio a entregar o a llevarse documentos, frecuentemente la salida de documentos se realizaba en su presencia, ella recibía los documentos y a ella acusaba recibo el rey del material enviado. Su sello cierra en una ocasión un saquillo de documentos que se sacan del monasterio en 1256.

Normalmente, el rey envía a una persona de confianza (sobre todo, escribanos reales) con carta credencial para la priora y órdenes expresas a ésta para facilitarle el acceso a la documentación. La persona que es enviada lleva instrucciones de buscar determinados documentos. El tenor de las actas y anotaciones de salida de documentos y de las órdenes de búsqueda no permite aclarar si existió un inventario de la documentación depositada, puesto que si bien en ocasiones se busca documentación precisa, en otras se ordena acceder al fondo por ver si hay determinado documento. De todos modos, existen verdaderas actas de depósito de las que es difícil precisar si quedaron en poder del

${ }^{70}$ Ubieto Arteta, Antonio: El real monasterio de Sijena (1188-1300), Valencia, 1966, p. 19 (citado por CONDE, Rafael: El archivo real del monasterio de Santa María de Sijena...) 
monasterio o del rey. Hallado el documento requerido, se deja constancia de su salida, sea en forma de albarán, que queda en manos de la priora, sea en anotación en un volumen habilitado para ello de mano normalmente de quien retira o deposita los documentos. Una vez salidos, en ocasiones se da acuse de recibo por parte del rey ${ }^{71}$.

Tras rigurosos estudios sobre los documentos conservados en Sijena, Conde consiguió identificarlos y localizar sus referencias actuales ${ }^{72}$. De los 314 documentos reales que hubo en Sijena, 187 son del reinado de Jaime I, sólo 5 de Alfonso el Liberal y ninguno de Pedro el Grande. Por territorios, 112 son relativos al reino de Aragón, seguidos de los de Valencia (47), y Cataluña (29). Otro grupo de documentos corresponde a 107 bulas y rescriptos pontificios, en su inmensa mayoría dirigidas a Jaime I. Un tercer grupo, más reducido,lo constituyen los relacionados con el reino de Navarra, a raíz de las pretensiones de Jaime I y de su hijo el infante Pedro, al trono de Navarra a la muerte de Teobaldo II. Es interesante reseñar que en 1269 el infante Jaime, con autorización de su padre, retiró del monasterio toda la documentación relativa a Mallorca, Montpellier, Rosellón, Cerdaña y Conflent (constituida por 31 instrumentos y 3 escrituras en papel), que correspondía a su herencia ${ }^{73}$.

Así pues, Jaime I concentró en Sijena documentación no condal y, con preferencia, producida o recibida por él. Según Conde, la documentación, unas 500 piezas a lo sumo, se hallarían en un arca, lo que no excluye que en su interior hubiera cajas con contenidos monográficos. Salvo alguna anecdótica excepción, los documentos allí depositados son todos posteriores a Ramon Berenguer IV, cubren los reinados de Alfonso el Trovador, Pedro el Católico y sobre todo, el suyo propio. Apenas hay documentos de sus inmediatos sucesores Pedro el Grande y Alfonso el Liberal. Grosso modo los documentos conservados -y que Conde realiza la proeza de localizar sus signaturas actuales en la mayoría de los casos - afectan al patrimonio real aragonés (ventas, donaciones, permutas de castillos y villas, de caballerías, etc.), a las relaciones internacionales (acuerdos con Navarra, Francia y Castilla); a los nuevos reinos conquistados, Valencia sobre todo; y a sus conflictivas relaciones con el infante Alfonso. En Sijena se mantuvo el depósito de documentos reales hasta que en 1308 Jaime II ordenó que se lo remitieran ${ }^{74}$. Ya veremos en qué circunstancias se produjo este traslado. Por este documento, ya citado y sobre el que volveremos, confirmamos que la documentación la depositó Jaime I y que estaba constituida por quamdam archam et quamdam caxiam in quibus erant instrumenta plurima et alie scripture.

Sijena nos ofrece una información preciosa sobre el estado de los depósitos documentales aragoneses en el siglo XIII. En primer lugar, su funcionamiento como

71 Estas apreciaciones, las referencias documentales y muchos más detalles que aquí se omiten en CONDE, Rafael: El archivo real del monasterio de Santa María de Sijena...

72 CONDE, Rafael: El archivo real del monasterio de Santa María de Sijena...

73 CONDE, Rafael: Reyes y archivos..., docs. 12, 13 y 14.;

${ }^{74}$ CONDE, Rafael: Reyes y archivos..., doc. 30. 
archivo se limita a mero depósito de documentos, carente de una función como fe pública. El rey solicita con frecuencia que se le remitan documentos para estudiar los antecedentes de determinados asuntos, algunos de gran calado político. Pero no hay constancia de que se pidan instrumentos para ser presentados en un tribunal ni que la priora, como responsable del depósito ante la cual se realizan las entradas, salidas o consultas de documentos, extienda certificaciones. Cuando el rey le solicita el traslado de un documento (por ejemplo, en 1270, el del prohijamiento mutuo entre Jaime I y Sancho VII de Navarra), estas copias autorizadas las realiza un notario con el testimonio de la priora, que asiste con otros testigos, entre ellos otras monjas de su monasterio así como el prior y el comendador del monasterio dúplice de freires de la misma orden al cual estaba adosado ${ }^{75}$.

El depósito de documentos de Sijena está, pues, en un lugar sagrado, pero no en un lugar privilegiado de fe pública, tal como lo concebían los glosistas. En este sentido, con los documentos del rey, el monasterio perpetúa la función que en el pasado había ejercido respecto de los documentos que los particulares habían confiado a la comunidad de monjas para su custodia y conservación entre sus gruesos muros, en tiempos de grandes tribulaciones, y no tanto para comunicarles fe pública. En efecto, los reyes solían depositar en monasterios documentos y objetos preciosos: por ejemplo, en abril de 1307, se depositó en Santes Creus una caja que contenía joyas y objetos preciosos de la Casa real. Esta caja la reclamó Jaime II al abad en noviembre de $1318^{76}$. Precisamente en Santes Creus piensa Trenchs que pudo existir un depósito de privilegios reales, a juzgar por el envío en 1281, por orden del rey Pedro, del escribano Pere de Sant Climent con once cartas ibi suo nomine [del rey] deponendas ${ }^{77}$.

El archivo de Sijena se documenta desde 1255 . Su aparición coincide con la consolidación de la burocracia administrativa de la monarquía tras la conquista de Valencia, una vez alcanzados los límites asignados al rey de Aragón en el tratado de Almizra. Precisamente, los registros de Cancillería que se conservan hoy comienzan en 1257. Burns y Trenchs, entre otros, han estudiado a fondo la documentación y la cancillería de Jaime I y a ellos nos remitimos ${ }^{78}$. Pero todavía no se ha explicado de manera convincente cómo y por qué comenzó a formarse esta serie de los registros de la Cancillería regia. El estudio de los archivos reales ha merecido menos atención aún.

Conde piensa que el depósito documental de Sijena fue degradándose por el procedimiento tan usual en todas las administraciones como es el de no devol-

75 CONDE, Rafael: El archivo real del monasterio de Santa María de Sijena..., docs. XIV y XVII.

76 Martínez Ferrando, Jesús Ernesto: Jaime II de Aragón. Su vida familiar, Barcelona, 1948, p. 258.

77 Trenchs Ódena, José: Casa, corte y cancillería de Pedro el Grande (1276-1285), Roma, 1991, p. 150.

78 Burns, R. I.: Diplomatarium..., vol. I; y TREnChs ÓdenA, José: «La Cancillería de Jaime I: cancilleres y escribanos", en Studi in onore di Giulio Batteli (Roma) 1979, pp. 97-128, entre otros muchos autores que no citaremos para no ser prolijos. 
ver la documentación extraída del archivo. Las noticias conservadas permiten sospechar que salieron más documentos que los que se devolvieron, sobre todo concluido el reinado de Jaime I, que fue quien lo creó. La documentación conservada en Sijena apenas pasa del reinado de Jaime I. De Pedro el Grande no hay ningún documento recogido, y sólo constan extracciones de documentos anteriores. De Alfonso el Liberal apenas hay cinco documentos. Tanto el uno como el otro abren una nueva fase, de transición, en la historia de la Corona de Aragón y en la de sus archivos.

El caso del depósito documental de Sijena se conoce porque se han conservado en el ACA las numerosas cartas de Jaime I y de sus sucesores dirigidas a la priora solicitando documentos, así como diversas relaciones de los instrumentos en él conservados. Quizá ha sido así por el mayor volumen que alcanzó, en vista de la predilección que el Conquistador sintió por esta casa. Pero estos depósitos, acaso de menor envergadura, debieron existir en otros monasterios con especiales vinculaciones a la Casa real. Hemos citado ya el de Santes Creus. De 1274 es una nota registral del envío de órdenes a los monasterios de Sijena, San Juan de la Peña y de Montearagón para que remitieran al rey, en original y traslado, documentos relativos a las pretensiones aragonesas sobre Navarra ${ }^{79}$. También los hubo en las casas de los predicadores de Zaragoza y Valencia, en 1240 y 1263 , respectivamente ${ }^{80}$. Estos depósitos reales deben distinguirse de la simple acumulación de documentos que quedaban en manos de los oficiales reales en el ejercicio de su administración, sobre los cuales el rey podía también intervenir, como es natural. Por ejemplo, en 1266 Jaime I da amplios poderes a Joan Blac (?) para poner en orden ciertos aspectos de la administración de Montpellier. Entre estos poderes, se incluye la capacidad para registrar o hacer registrar sus documentos et querenda, petenda et recuperanda ea omnia et singula instrumenta a quibuscumque detinentur vel possidentur ${ }^{81}$.

\section{ArChivos ReAles en tiempos de PEdro el GRANDE y Alfonso El Liberal.}

Pocas son las referencias de las que disponemos acerca de los archivos durante estos reinados. ${ }^{82}$ Las dos últimas noticias localizadas relativas al uso o consulta del depósito de Sijena son de 1278. De mayo es una orden de Pedro el Grande a la priora de Sijena para que facilite a Miguel Violeta el acceso a los documentos relativos a las relaciones de Aragón con Castilla (dicimus et manda-

79 CONDE, Rafael: Reyes y archivos..., doc. 17.

80 BURns, Robert Ignatius: Diplomatarium..., vol. I, pp. 20-21, n. 13.

81 CONDE, Rafael: Reyes y archivos..., sobre un documento comentado y publicado por Bofarull, Francisco de: «Don Jaume i l'Arxiu Reial», en Boletín de la Real Academia de las Buenas Letras (Barcelona), t. IV (1907) pp. 254-255.

82 Sobre los importantes cambios introducidos en la administración real durante el reinado de Pedro el Grande, Trenchs ÓdenA, José: Casa, corte y cancillería... 
mus vobis quatenus cartolaria in quibus sunt aut esse debere putetis dicta instrumenta ostendatis) $^{83}$. De diciembre es una nota registral de la entrega de un total de treinta documentos procedentes de Sijena relativas a las relaciones de Aragón con Castilla, hecha por Ramon Escorna a Pere de Sant Climent ${ }^{84}$.

Son pocas, pero sustanciosas, porque a la vista de ellas hay indicios para sospechar que el papel que las sanjuanistas de Sijena habían ejercido con Jaime I quizá aspiraron a cubrirlo los del Temple bajo el reinado de su hijo o incluso durante los últimos años del gobierno de Jaime I. En un mundo donde las relaciones sociales estaban siendo crecientemente juridificadas, se comenzaba a ser conscientes del valor de la información y de la documentación a la hora de ejercer el poder y garantizar los derechos de los particulares, y por tanto, se vislumbraba la importancia de controlar el acceso a los documentos.

Disponemos de una noticia preciosa de 3 de enero de 1282. La menciona de pasada Burns, pero con algún error de lectura y contextualización, comprensible dado la restringida especialización del tema que tratamos ${ }^{85}$. En esta fecha, Pedro el Grande escribe al comendador del Temple en Valencia. Le comunica que Jaume Sarroca, obispo de Huesca, depositó quadam caxia in domo vestra in qua sunt privilegia et instrumenta domus Sanct Vincentii. Ahora Bernardo, abad de San Victorián, quiere reclamar algunos derechos de su monasterio y por tanto necesita esas cartas y privilegios. Por este motivo, el rey, que data la carta en Valencia, ordena al comendador del Temple en aquella ciudad llevar esta caja ante el soberano para que, en presencia del monarca, del comendador y de otro religioso, se abra, se examinen los documentos y se den al abad los que necesite para reclamar sus derechos ${ }^{86}$.

La casa u Hospital y monasterio de San Vicente en Valencia había sido fundada por Jaime I pro remedio animae suae et parentum suorum y estaba bajo su patrocinio. En 1263, el rey le había donado su capilla con todo su tesoro, donación que había de tener efecto a su muerte ${ }^{87}$. En 1269, Jaime I dotó seis capellanías, entre otros beneficios ${ }^{88}$. En abril de 1283, Pedro el Grande mandó que, transcurridos dos años, el abad de San Victorián fuese prior del monasterio de

83 CONDE, Rafael: Reyes y archivos..., doc. 18.

84 CONDE, Rafael: Reyes y archivos..., doc. 19.

85 BURNS, Robert Ignatius: Diplomatarium..., vol. I, p. 21, n. 14.

86 Comendatori domus Templi Valencie. Cum intellexerimus per venerabilem fratrem Bernardum, abbatem Sancti Victoriani, quod per venerabilem Jacobum de Rocha, Oscensis episcopum, seu per P. de Rege, fratrem eiusdem, fuit deponita quadam caxia in domo vestra, in qua sunt privilegia et instrumenta domus Sanct Vincentii, et intersit eiusdem abbatis iura ipsius domus petere et exigere qua proest ipsi domui et indigeat quibusdam cartis et privilegiis pro petendis et recuperandis iuribus ipsius domus, mandamus vobis quatenus predictam caxiam coram nobis deferri faciatis, et in presencia vestri et alicuius discreti viri religiosi, faciemus ipsam caxiam aperire, et visis ipsis privilegis et cartis, faciemus dare ex eis dicto abbati ea qua sibi neccesaria fuerint pro predictis iuribus exhigendis. Datum Valencie III ${ }^{\circ}$ nonas januarii. P. Marchessii. (ACA, Real Cancillería, reg. 50, fol. 223v.)

87 ACA, Real Cancillería, reg. 12, fol. 79v.

88 ACA, Real Cancillería, reg. 16, fol. 181. 
San Vicente ${ }^{89}$. Pere de Rei, sacristán de Lérida, era prior de esta casa. En enero de 1286, nada más comenzar el reinado de Alfonso el Liberal, pleiteó ante este rey porque su padre le había privado y expoliado de su priorato sin causa ${ }^{90}$. El pleito fue comisionado al procurador del reino de Valencia, que falló a favor del sacristán. La sentencia fue confirmada por el rey Alfonso ${ }^{91}$.

Varias son las conclusiones que sacamos de este documento. En primer lugar, que los privilegios reales fundacionales del monasterio de San Vicente y otras escrituras, por ser un establecimiento real, no estaban en poder del propio monasterio sino que el rey había constituido un depósito en otra casa religiosa de su especial confianza, la del Temple. Este depósito lo había realizado Jaume Sarroca, obispo de Huesca, individuo muy conocido, canciller de Jaime I en sus últimos años de reinado, persona muy próxima al monarca, redactor de su testamento y a quien algún autor ha llegado a atribuirle la autoría del Llibre dels feyts $^{92}$. Sabemos que los privilegios de San Vicente depositados en la casa del Temple de Valencia por Sarroca (precisamente, a través de su hermano, Pere de Rei) estaban en una caja, pero nada más conocemos de este posible depósito de documentos reales en aquella casa. Por ejemplo, si hubo otras cajas con otra documentación real, como en Sijena. En segundo lugar, constatamos que, como en Sijena años antes y más tarde en la casa del Hospital, el Temple actúa como mero custodio de la documentación: no se encarga ni de la gestión de la documentación o su consulta ni de librar copias o testimonios. En tercer lugar, el acceso a la documentación sólo es posible con autorización real. Ni siquiera le está permitido al prior del monasterio porque, al ser patronato real, los privilegios otorgados por los reyes comprometen en primer lugar al monarca. E incluso es posible, aunque lo ignoremos, que este depósito en la casa del Temple se realizara por orden del rey, oral o escrita. En este caso, además, vemos que hay por medio cuestiones litigiosas que afectan a terceros, por un lado, pero que, además, el propio rey ha actuado ilegalmente, como se demostró en el reinado siguiente, y está interesado por tanto en que el examen de la documentación sea realizado en su presencia para controlar los documentos que se librarán. En cuarto lugar, constatamos que la veracidad que se otorga al depósito de documentos del Temple está ligada a la custodia ininterrumpida del mismo, hasta el punto de que la caja se debe abrir en presencia del comendador y de otro testigo religioso, pero que este lugar por sí mismo carece aún del privilegio de comunicar fe pública.

No es la única noticia relativa al Temple de este reinado. En mayo de 1285, Pedro el Grande da una orden al comendador de la casa del Temple en Barcelona y a Esclaramunda, esposa de Jaume de Sant Climent, escribano de la

89 ACA, Real Cancillería, reg. 44, fol. 225.

90 ACA, Real Cancillería, reg. 63, fols. 37v-38.

91 ACA, Real Cancillería, reg. 63, fols. 53v-54.

92 Es el caso de RIERA I SANS, Jaume: «La personalitat eclesiàstica del redactor del Llibre dels feyts» en X Congreso de Historia de la Corona de Aragón, Zaragoza, 1982, vol. 3,4 y 5, pp. 575-589. 
reina, a fin de que, por necesitar algunos documentos que supone están en su cartholario Barchinone, permita a Jaume de Bianya el acceso a los registros y escrituras, las cuales parece autorizado a sacar, tradentes sibi cum albarano quod ab eo receperit ${ }^{93}$. González Hurtebise y Martínez Ferrando creen que este era el nombre del Archivo Real en tiempos de aquel rey ${ }^{94}$. Pero, a juzgar por este documento y por lo que hemos visto a propósito de Sijena, este cartolario estaba en la casa del Temple. Por eso, parece diferente del depósito existente en 1286 en el palacio real, bajo la custodia del repostero, según hemos tenido ocasión de ver en la orden de Alfonso el Liberal a Pere de Sant Climent, ya citada, para buscar documentos en una caxia blancha ${ }^{95}$.

¿A cuál de los dos fueron los veintidós documentos con sellos y otros ocho sin sellos que, procedentes de Sijena, entregó Escorna a Pere de Sant Climent en 1278? Probablemente, a ninguno. Pere de Sant Climent fue jefe de la escribanía con Pedro el Grande ${ }^{96}$. Y en su casa o en las oficinas de la escribanía o cancillería real parecen conservarse los documentos en uso o en trámite, por lo menos lo que hoy se denominaría "archivo corriente», sobre todo a medida que la burocracia crecía y la documentación se multiplicaba. Cuando, con motivo del reinado de Alfonso el Liberal, la jefatura de la escribanía pasa en 1286 de Sant Climent a Pere Marqués, el rey extiende un recibo a favor de Sant Climent por haber entregado a Marqués nueve registros del rey Jaime y veintiuno del rey Pedro, además de otros muchos instrumentos que tenía in scribaniiis ${ }^{97}$. En casa de Sant Climent, que continuó como escribano del rey, quedaron varios libros, los cuales a su muerte una orden del rey de 1291, redactada por Pere Soler, dispuso que pasaran al baile de Barcelona, excepto dos que fueron

93 CONDE, Rafael: Reyes y archivos..., doc. 20.

${ }_{94}$ El Archivo de la Corona de Aragón..., p. 33.

95 CONDE, Rafael: Reyes y archivos..., doc. 22. Trenchs ÓdenA, José, y Aragó CaBAÑAS, Antonio María: Las cancillerías de la Corona de Aragón y Mallorca desde Jaime I a la muerte de Juan II, Zaragoza, 1983, p. 32, afirman que la ciudad de Barcelona era «sede del Archivo principal. Tenemos un texto de 1289 por el que Alfonso II ordenó a su Tesorero Arnau Sabastida que pagara a un notario 50 sueldos barceloneses por el traslado de diversos documentos reales guardados en el archivo real». Se remiten a ACA, Real Cancillería, reg. 72, fol. 28. Allí en efecto se encuentra la siguiente anotación: A. de Bastida, quod solvat Petro Marci, notario Barchinone, L. solidos barch. quos dominus Rex sibi concessit pro quibusdam transllatis que sibi fecit de diversis instrumentis. Datum Barchinone $X I^{0}$ kalendas aprilis. No se menciona, por tanto, el archivo real. Si Trenchs y Aragó querían referirse a otra nota registral, no la hemos encontrado en ese folio.

96 Trenchs Ódena, José, y Aragó Cabañas, Antonio María: Las cancillerías..., pp. 20 y $27-$ 28; CÁrCel Ortí, María Milagros: «Pere de Sant Climent, notario mayor de Pedro III, el Grande», en XI Congreso de Historia de la Corona de Aragón, Palermo, 1983, vol. II, pp. 303-310; y TrENCHS Ódena, José: Casa, corte y cancillería..., pp. 26 y ss. Para J. E. MARTíneZ Ferrando, Sant Climent "figura como el encargado del registro y custodia del archivo». Se basa en los documentos que aquí se mencionan (El Archivo de la Corona de Aragón..., p. 36).

97 Conde, Rafael: Reyes y archivos..., doc. 21; Trenchs ÓdenA, José, y Aragó CaBAÑAS, A. $\mathrm{M}^{\mathrm{a}}$ : Las cancillerías..., p. 28. Sobre Pere Marqués, véase también TrenCHS ÓdENA, J.: Casa, corte y cancillería..., pp. 30-31. 
entregados a Pere Marqués, y que Trenchs y Aragó identifican con el Liber Feudorum Maior y el Liber Feudorum Ceritanie, sin dar argumentos ${ }^{98}$. Recordemos también que en 1286 Pere de Sant Climent parece responsable, si quiera temporalmente, de la caja de documentos a cargo del repostero, por lo que es fácil que alguna documentación se quedara en su casa. Sabemos que en 1303 Jaime II ordenó a su escribano Mateu Botella recuperar la documentación y los procesos realizados por el difunto juez de curia Nadal Reiner, y que todas estas escrituras inclusas in saco vel alias ad cancelleriam nostram protinus transmitatis ${ }^{99}$. Los documentos de Sijena que se trasladan a Barcelona en 1308 fueron ad cancellariam nostram, según reconoce en 1308 Jaime II a la priora Teresa Jiménez de Urrea ${ }^{100}$. Este «archivo corriente» de la Cancillería, que incluía registros y escrituras sueltas, y que la acompaña en sus desplazamientos junto al rey, fue el que había ardido años antes cuando un grupo de caballeros aragoneses, disgustados con Jaime I porque les había otorgado propiedades en el Reino de Valencia según uso de Cataluña y no a fuero de Aragón, puso fuego a la posada donde circunstancialmente se alojaba la escribanía. ${ }^{101}$

Que existía este archivo corriente en las oficinas de la Cancillería, cosa lógica por lo demás, lo ratifica un documento algo posterior al momento que estamos tratando aquí. El 8 de marzo de 1327, Arnau Messeguer, camarero del rey, obtiene la aprobación real de un albarán definitorio de cuentas otorgado a su favor por el maestre racional Felip de Boill, con fecha de 25 de febrero del año anterior y por 12.064 sueldos y 11 dineros. Se refiere a los gastos de la reedificación de unes cases que eren contigües al seu palau, davant la esglea de la Seu de Barchinona, les quals cases eren velles e decabudes para ubicar la sua scrivania ab los seus segells e ab los registres ${ }^{102}$. Se trata de unas edificaciones adosadas a la cambra dels paraments o "Tinell», que se abrían a la calle de la Escribanía, desaparecida al construirse en el s. XVI el Cuarto Nuevo del Lugarteniente, que ocupó el solar de las escribanías, de la calle y de unas casas particulares que había entre la calle de la Escribanía y la actual Bajada de Santa Clara ${ }^{103}$.

98 Mandamus (...) tradatis fideli nostro Bartholomeo de Villafrancha, baiulo Barchinone, omnia capibrevia, libros et scripta que sunt nostra vel faciant pro aliquibus negotiis nostris, exceptis duobus capibrevis magnis pergameneis confectis super convenientiis et feudis nostris Cathalonie, que volumus tradatis $P$. Marchesii (ACA, Real Cancillería, reg. 82, fol. 124). Cfr. Trenchs Ódena, J. y ARAGó Cabañas: Las cancillerías..., p. 28.

99 CONDE, Rafael: Reyes y archivos..., doc. 23.

100 CONDE, Rafael: Reyes y archivos..., doc. 30.

${ }_{101}$ Cfr. Martínez Ferrando, Jesús Ernesto: El Archivo de la Corona de Aragón..., p. 31. El documento transcrito por CONDE, Rafael: Reyes y archivos..., doc. 43.

102 CONDE, Rafael: Reyes y archivos..., doc. 37.

${ }^{103}$ CONDE, Rafael: Reyes y archivos... 


\section{El depósito de documentos Reales en la CASA del Hospital de SAN JUAN DE JERUSALÉN EN BARCELONA.}

Como señala Conde, bajo Jaime I aun no hay una capitalidad administrativa clara. Lo más parecido, fue Lérida, y por eso Sijena ocupó una posición central. Lo será Barcelona cuando se consolida el aparato administrativo bajo sus sucesores, Pedro el Grande, Alfonso el Liberal y, sobre todo, Jaime II, que creó una máquina burocrática de producción de documentos. Cuando la administración madura, la exigencia de una capitalidad administrativa es evidente. Y al consolidarse Barcelona como tal, los archivos de la monarquía tendieron a trasladarse a esta ciudad ${ }^{104}$.

No será necesario recordar aquí la profunda impronta que dejó Jaime II en la organización administrativa de la Corona de Aragón desde su entronización en 1291. Merced a la política dinástica de la Casa de Aragón, Jaime II había gobernado Sicilia desde la conquista de este reino en 1283 (como rey de la isla desde la muerte de su padre, Pedro el Grande, en 1285) hasta que la abandonó para ser coronado rey de Aragón. Muchas de las reformas que después implantaría en sus reinos ibéricos estuvieron inspiradas en el fuerte desarrollo burocrático que el de Sicilia había tenido, especialmente bajo el gobierno de Federico II. Como hemos mencionado ya, allí se habían tomado también algunas tempranas medidas legislativas sobre los archivos.

Fue entonces cuando la cancillería aragonesa alcanzó su madurez y tuvo una organización que, en muchos aspectos, sería definitiva, quizá bajo la influencia pontificia, recibida por conducto siciliano. Se estabilizaron entonces los cargos de canciller, de vicecanciller y de notario guarda-sellos, que ocupó durante muchos años Bernat d'Aversó, cuya capacidad de acción sobre la intensa actividad política de Jaime II fue notable ${ }^{105}$. Además de la influencia sicilinana, $\mathrm{o}$ incluso de los registros angevinos ${ }^{106}$, las novedades introducidas en la Cancillería aragonesa pudieron hacerse directamente a imitación de la pontificia por iniciativa de Ramon Despont, obispo de Valencia desde 1288 y canciller a partir de $1295^{107}$. El resultado fue que creció la producción de documentos. Es bien conocida y ha sido muy comentada la afición de Jaime II por la escritura, rey «papelista» donde los hubiera. Si el número de registros completados du-

${ }_{104}$ CONDE, Rafael: El archivo real del monasterio de Santa María de Sijena...

105 Martínez Ferrando, Jesús Ernesto: El Archivo de la Corona de Aragón..., pp. 36-37.

106 Kiesewetter, A.: «La cancellaria Angioina», en L'État angevin. Pouvoir, culture et société entre $X I I I^{i m e}$ et XIV $V^{\text {ime }}$ siècles (Actes du Colloque international organisé par l'American Academy in Rome, l'École Française de Rome, l'Istituto storico italiano per il Medio Evo, l'U.M.R. Telemme et l'Université de Provençe, l'Università degli studi di Napoli Federico II, Roma-Naples, 7-11 novembre 1995), Roma, 1998, pp. 361-415.

107 Trenchs Ódena, José, y ARAgó Cabañas, A. Mª Las cancillerías..., pp. 40-50. La influencia de Jaime II sobre el ACA, brillantemente expuesta por MARTínEZ FERRANDO, Jesús Ernesto: Archivo de la Corona de Aragón..., pp. 34-37. 
rante el reinado de Jaime I es de 0,56 por año, 2,6 para Pedro el Grande, 5,4 para Alfonso el Liberal, la cifra se eleva a 9,3 registros por año bajo Jaime II $^{108}$, datos que, para quien conozca esta serie documental, no tienen más que un valor meramente ilustrativo.

Sijena había dejado de recibir nuevos ingresos documentales con Pedro el Grande. Solo se incorporaron unos pocos de Alfonso el Liberal. Con el traslado de la centralidad de la Corona hacia Barcelona, el nuevo monarca Jaime II buscó otra casa religiosa que le sirviera de depósito documental. Sijena era sanjuanista, y en la Casa de San Juan de Jerusalén de Barcelona se constituyó otro importante depósito.

La primera noticia que tenemos es de julio de 1301, cuando Jaime II reconoce al comendador y al prior de la casa de San Juan de Jerusalén de Barcelona, que ha entregado a su escribano Pere Llobet ciertos registros y volúmenes. Entre ellos, se citan tres libros sive registra illustrissimi domini regis Jacobi, clare memorie avi nostri, confecta super divisionibus tunc factis per dictum dominum regem, avum nostrum, de hereditatibus regni Valencie, et duo registra parvula, unum videlicet factum super commissione per dictum dominum regem Alfonsum, inclite memorie fratem nostrum, facta de officio comisso Petro Peregrini, et aliud super comissione per nos facta de eodem officio fideli nostro Berengario de Manso, de domo nostra. Estos libros y registros estaban inter alia registra nostra que sunt deponita in domo Hospitalis predicti y los depositó Llobet in cancelleria nostra ${ }^{109}$. Parece, pues, que esta documentación se reclama desde lo que hoy se llamaría el «archivo histórico» (en la casa del Hospital) para ser llevados al «corriente» o «de gestión», situado en la propia Cancillería, que en ese momento se encontraba con el rey en Lérida, desde donde se data este albarán. De 1303 es otra orden real dada al prior de los predicadores y al comendador de la casa de San Juan de Jerusalén, de Barcelona, para colaborar con el escribano real Mateu Botella en la búsqueda y traslado quorumdam instrumentorum continencium pacta que inter illustrem Alfonsum, regem Castelle, et nos inita sunt queque reposita sunt in scriniis sive caxiis nostris quas habemus in domo dicti Hospitalis ${ }^{110}$.

En la casa del Hospital en Barcelona, pues, se constituye en los primeros años del reinado de Jaime II un nuevo depósito, en el que se concentran los documentos reales, tanto los que produce el monarca como otros que se solicita su remisión a la Corte para quedar ya en aquella ciudad, más próximos a la cancillería y al alcance del soberano. Allí se conservaban parte de los registros producidos desde los tiempos de Jaime I, no sabemos desde qué fecha. El 7 de mayo de 1306, Mateu Botella recibe una orden del rey para buscar y enviar traslado de las donaciones de Vespen y Peraciels a Alamán de Gúdar con servi-

108 Ibídem, p. 46.

109 ACA. Real Cancillería, Cartas Reales, Jaime II, 3.201 (recogida por Bofarull, Francisco de: (Historia...), doc. XV).

110 ACA. Real Cancillería, reg. 130, fols. 177v-178v. (Citado por CONDE, Rafael: El archivo real del monasterio de Santa María de Sijena...) 
cio de un caballo armado por cada lugar. Debía buscar cartas super dictis donacionibus confectas in registris dicti domini regis Alfonsi que sunt in armario nostro in domo Hospitalis Barchinone, cuius claves fidelis scriptor porcionis domus nostre Petrus Marci vobis tradet. De estos documentos debía sacar traslado cerrado y sellado para enviarlo a la Cancillería real. Esta orden incluye buscar todo cuanto pueda tocar al patrimonio real en los registra omnia que sunt in dicto armario, tam dominorum regum Jacobi avi, Petri patris, Alfonsi fratris nostrorum et nostra ${ }^{111}$. Así lo hizo Botella. En el preámbulo de su trabajo, declaró que en el armario del rey en la casa del Hospital sólo encontró registros de los predecesores de Jaime II desde Jaime I, Pedro el Grande y Alfonso el Liberal ${ }^{112}$. Botella sacó noticias de veinticuatro registros: diez de Jaime I, tres de Pedro el Grande, cuatro de Alfonso el Liberal y siete de Jaime II. Los registros son identificados por Botella a partir de su encuadernación, de sus incipit, y de ciertos signos gráficos convencionales (rosa, cruces de formas diversas, flor de lis, pájaro, estrella, letras, etc.) existentes en la cubierta ${ }^{113}$. El inventario de Botella confirma que el depósito de registros y otros documentos reales en la casa del Hospital en Barcelona no debía ser muy antiguo, porque de otro modo no se entiende que se redactara en ese momento ${ }^{114}$. Al igual que Sijena, el Hospital funciona como mero depósito de

${ }^{111}$ Jacobus, Dei gracia rex Aragonum, Valencie, Sardinie et Corsice comesque Barchinone ac Sancte Romane Ecclesie amirantus et capitaneus generalis, fideli scriptori suo Matheo Botella, salutem et graciam. Scire vos volumus nobis fuisse datum intelligi quod per illustrem dominum Alfonsum, clare memorie regem Aragonum fratrem nostrum, fuerunt data et concessa Alamanno de Gudar et suis loca de Vespen et de Paraciels, retento servicio pro quilibet loco unius equi armati. Et cum nos de biis quommodo processerunt habere velimus certitudinem pleniorem, volumus et vobis dicimus et mandamus quatenus, visis presentibus, cartas super dictis donacionibus confectas in registris dicti domini regis Alfonsi que sunt in armario nostro in domo Hospitalis Barchinone, cuius claves fidelis scriptor porcionis domus nostre Petrus Marci vobis tradet, cum diligencia perquiratis et, perquisitis, translatum earum clausum et sigillatum ad nostram cancelleriam per dictum Petrum Marci quam cicius transmitatis. Ceterum, quia pro valitate curie nostre et eius indempnitate providimus quod vos registra omnia que sunt in dicto armario, tam dominorum regum Jacobi avi, Petri patris, Alfonsi fratris nostroum et nostra perquiratis, et cum dillegencia sollicite attendatis ad ea que in registris ipsis inveneritis faciencia pro nobis et curia nostra quibuscumque modis vel causis, tam in donacionibus sub condicionibus qualitercumque factis quam modis aliis quibuscumque. Ideo vobis dicimus et mandamus quatenus premissa omnia diligenter perquiratis et attendatis ad ea que videbuntur pro nobis vel curia nostra facere quoquomodo, et in scriptis ea cum diligencia redigatis seu redigi faciatis, et de ipsis nos certificare curetis prout nobis videbitur expedire. Sane quia premissa non poterunt sic breviter expediri, volumus et mandamus ut, intendendo circa hec in civitate Barchinone, non curetis venire ad curiam nec eam appetere donec nos in civitate ipsa fuerimus consituti. Tunc etenim nos providemus super hiis et fuerit opportunum. Datum Valencie, nonas madii anno Domini $M^{o} C^{\circ} C^{o}$ sexto. (ACA. Real Cancillería, Cartas Reales, Jaime II, 2.696 interino. Transcrita por BofArUlL, Francisco de: (Historia...\}, doc. XVI).

112 CONDE, Rafael: Reyes $y$ archivos..., doc. 24.

113 GONZÁLEZ HuRTEBISE, Eduardo: Guía..., p. 12, da una identificación fiable, a pesar de que la pérdida de algunos folios y de las cubiertas originales, y su posible manipulación en la reencuadernación posterior la hagan algo dificultosa (Cfr. CONDE, Rafael: Reyes y archivos...)

${ }^{114}$ Los inventarios realizados por Botella, los describe RIERA I SANS, Jaume: Catálogo de memoriales e inventarios, siglos XIV-XIX (Archivo de la Corona de Aragón), Madrid, Ministerio de Educación y Cultura, 1999, 143 págs. 
unos muebles con documentos que el rey les confía para su custodia. El movimiento de fondos queda controlado por los funcionarios de la Cancillería regia, cuyos escribanos son los que redactan los traslados autorizados de documentos. Aun no han confluido, pues, custodia de documentos, control del acceso y fe pública, como veremos enseguida.

También en mayo de 1306, se relacionan veinticuatro documentos y un registro que tradita fuerunt Petro de Solerio, scriptori domini regis, per Bernardum de Aversone, scriptorem eiusdem domini regis, de mandato ipsius domini regis, in Calataiubio die jovis VII kalendas junii anno Domini M CCC VI reponenda per dictum Petrum de Solerio in caxiis ipsius domini regis que sunt in domo Hospitalis Barchinone. Al pie de esta relación o albarán, se hace constar que Pere de Soler reescribió al rey y Bernat d'Aversó para confirmar que este depósito se efectuó. Todos los documentos, salvo uno, son de los reinados de Alfonso el Liberal y Jaime II, y afectan a diversos negocios y materias de todos los reinos de la Corona ${ }^{115}$. Esta documentación se trae desde Calatayud, sin que sepamos en qué casa y por qué razón estaba allí. Incluía un quoddam registrum factum in pergameno super sentencia lata per iusticiam Aragonum contra aliquos nobiles et milites Aragonum racione iuris. Conde lo identifica con el proceso que quedó incluido en la serie de registros bajo el título Causa mota contra nobiles unionis Aragonum, actualmente el número 350 de la serie. Como es sabido, estos procesos se habían iniciado en 1301, por lo que muy pronto habían pasado a ser custodiados en el depósito documental de Barcelona.

Así pues, desde 1301, aproximadamente, la casa de la orden del Hospital en Barcelona funciona si no todavía plenamente como archivo del rey, sí como depósito de documentos reales, al estilo de Sijena un cuarto de siglo antes. La confusión está servida, ayudada por la homofonía latina de archa y archia o archivia (archiva), que se utiliza como sinónimo de armario. Como ya hemos apuntado, acaso la formación de este depósito esté relacionada con el nombramiento de Bernat d'Aversó como notario guarda-sellos en septiembre de 1301, y las reformas introducidas en la Cancillería aragonesa (fueran bien a imitación de la pontificia, de la siciliana, de la angevina o bien innovaciones propias, o una confluencia de todas ellas) por iniciativa del canciller Ramon Despont, obispo de Valencia, a partir de $1295^{116}$. El depósito debió ir incrementando sus fondos con la documentación de una Cancillería más activa cada día. En 1304 Jaime II avisa a Roberto, primogénito del rey de Sicilia, que el rescripto acerca de la concesión del ducado de Calabria, será depositado in archivo nostro repositum ac utiliter conservatum ${ }^{117}$. Cierto es que no se indica dónde estaba este archivo real, aunque veremos que así se denomina cuatro años más tarde al depósito de documentos de la casa del Hospital en Barcelona.

115 ACA, Real Cancillería, Cartas reales, Jaime II, Serie general, núm. 3204. Transcrito por BOfARULL, Francisco de: (Historia...), doc. XVII. Lo cita e identifica las signaturas actuales CONDE, Rafael: El archivo real del monasterio de Santa María de Sijena... Lo transcribe en Reyes y archivos..., doc. 25.

116 Trenchs Ódena, José, y Aragó Cabañas, Antonio María: Las cancillerías..., p. 44.

117 Bofarull, Francisco de: (Historia...), doc. XXII. 
La primera intención del monarca hacia 1306-1307 debió ser concentrar en ella los fondos documentales reales dispersos por sus dominios. De entonces datan las órdenes de concentración que venimos comentando. El 7 de junio de 1307, desde Huesca, Jaime II reitera una orden al abad de San Juan de la Peña para que envíe a la curia regia, allá donde estuviera, los registros reales y todas las cartas y escrituras pertenecientes al rey que hubiera en aquel monasterio aragonés ${ }^{118}$. Allí había existido uno de los depósitos documentales de Jaime I y de sus antecesores $^{119}$, como hemos tenido ocasión de comprobar en $1274^{120}$. En la misma fecha, 7 de junio de 1307, Jaime II reclama al comendador de la casa del Temple en Zaragoza que le envíe, allá donde se encontrara el monarca, instrumenta seu carte, libri et alia scripta pro nobis et curia nostra faciencia seu ad nos pertinencia (...), por tener necesidad de ellos ${ }^{121}$. Las dos órdenes fueron despachadas por Bernat d'Aversó. Esta documentación se remitió a Huesca, donde estaba Jaime II, y desde allí viajó a Barcelona en una caja bajo la custodia de Pere de Soler, escribano del rey, que la depositó, cumpliendo sus órdenes, en la casa del Hospital en Barcelona. Soler llevaba para ello una carta del rey dirigida a Ponç de Montclús, prior de los frailes predicadores de Barcelona, y a Lope Eximén de Lliuranes, comendador de la casa del Hospital de Barcelona. El 12 de agosto de 1307, estos dos individuos escribieron a Jaime II, tal como lo había ordenado, para avisarle de la recepción de esta caja, a la que había acompañado un albarán con la relación de documentos que contenía, realizada en papel por el propio Soler ${ }^{122}$. También fue avisado el rey por Pere de Soler el 17 de agosto ${ }^{123}$.

Muy poco después, Jaime II reclamó a la priora de Sijena el arca y la caja en los que había instrumenta plurima et alie scripture que depositó Jaime $\mathrm{I}^{124}$. El recibo extendido por el rey de haberse ejecutado la restitución es de 8 de enero de 1308, por lo que la reclamación y devolución debieron producirse unas semanas o meses antes, es decir, en el otoño de 1307. El documento está extendido por Bernat de Font y en él se indica que se trasladaron ad cancellariam nostram, sin más especificaciones. De allí pasaron al monasterio de San Juan de Jerusalén, donde los encuentra Conde en una noticia de $1318^{125}$. Precisamente, el 13 de octubre de 1307 había tenido lugar la detención del gran maestre del Temple en París, y durante el otoño de aquel año comenzaron a llegar al rey de Aragón las noticias e informes sobre la prisión de los templarios y la confisca-

\footnotetext{
118 CONDE, Rafael: Reyes y archivos..., doc. 26.

119 BURNS, Robert Ignatius: Diplomatarium..., vol. I, p. 19.

120 CONDE, Rafael: Reyes y archivos..., doc. 17.

${ }^{121}$ CONDE, Rafael: Reyes y archivos..., doc. 27.

122 CONDE, Rafael: Reyes y archivos..., doc. 28.

123 CONDE, Rafael: Reyes y archivos... doc. 29.

124 CONDE, Rafael: Reyes y archivos..., doc. 30.

125 CONDE, Rafael: El archivo real del monasterio de Santa María de Sijena...
} 
ción de sus bienes en Francia y Navarra, aunque los rumores sobre una acción contra ellos ya circulaban desde el verano ${ }^{126}$.

Los documentos se concentran en la casa del Hospital para servir a los usos e intereses del monarca. En una carta sin fecha de Pere de Soler, escribano, de 27 de agosto, sin año (pero que debe ser 1307 o de 1312), responde a una orden de búsqueda de documentos realizada por escrito por Jaime II. El escribano se desplaza a la casa del Hospital y, en presencia del comendador, busca la carta y se la entrega al enviado del rey ${ }^{127}$. El procedimiento recuerda al de Sijena, tanto por la presencia del jefe de la casa (la priora, el comendador), que es el custodio y responsable de la documentación, como por librarse los documentos originales sin sacarse copia autorizada de ellos. Pero la actuación de un escribano del rey y la cercanía del depósito a la Cancillería real explica que muy pronto confluyan gestión del acceso al documento y fe pública, primero, y la custodia en una fase final. El cambio se refleja también en el uso de la palabra «archivo» aunque todavía con ciertas vacilaciones, como ya expusimos. En 1308 se sacan traslados de documentos de los registros conservados in archivo regio in domo Hospitalis Sancti Johannis Hierosolimitani Barchinone. Es de notar que este traslado está validado por el veguer de Barcelona y extendido por el notario público de esta ciudad que ejerce como regente la escribanía de la veguería de Barcelona ${ }^{128}$.

De documentos de los registros custodiados en la casa del Hospital, relativos a asuntos del valle de Arán acaecidos en 1278, se sacaron copias certificadas en septiembre de $1312^{129}$, refiriéndose a éstos como los registra regia in archivo regio posito in domo Hospitalis Sancti Iohannis Iherosolimitani, según otro traslado de septiembre de $1312^{130}$. Pero también se enviaron los originales. Con este último negocio parece estar relacionado el traslado de una caja con documentos relativos al Valle de Arán desde el mismo depósito hasta Lérida para su consulta: caxia illa que erat in archivo domini regis quod est in civitate Barchinona, apud Hospitale Sancti Jherosolimitani (...) ${ }^{131}$.

El depósito de documentos o archivo del rey en la casa del Hospital de Barcelona pronto alcanzó una importancia considerable, como sabemos por una relación, incompleta, de las escrituras sueltas allí existente procedentes de Sijena, con un total de unos 500 asientos, que incluyen documentos de Ramón

${ }^{126}$ El final de la Orden del Temple ha merecido muchos estudios. De los más recientes, Alan FOREY, The Fall of the Templars in the Crown of Aragon, Aldershot, 2001.

127 Bofarull, Francisco de: (Historia....), doc. XX, referido a ACA, Real Cancillería, Cartas Reales Diplomáticas de Jaime II, núm. 3.202.

${ }_{128}$ BOFARUlL, Francisco de: (Historia...), doc. XXI, referido a ACA, Real Cancillería, Pergaminos de Pedro II, núm. 170.

129 ACA, Cancillería, Perg. Pedro el Grande, 90 (Cfr. CONDE, Rafael: Reyes y archivos...)

130 ACA, Real Cancillería, Pergaminos, Pedro el Grande, núm. 198. También en el pergamino núm 197 de este rey figura esta misma fórmula.

${ }^{131}$ CONDE, Rafael: Reyes y archivos..., doc. 32. 
Berenguer IV, Alfonso el Trovador, Pedro el Católico y, sobre todo, de Jaime I, así como documentos papales, relativos a materias de todos los reinos y negocios de la Casa real. Algunos eran de excepcional importancia; por ejemplo, la donación del reino de Aragón hecha por Petronila a su hijo Alfonso II ${ }^{132}$.

\section{La CREACión del ArChivo ReAl de BARCELONA (Más tarde, ARCHivo DE LA CORONA DE ARAGÓN).}

En una larga relación escrita el martes día 17 de octubre, sin indicación de año (pero que, por las fechas, sólo puede ser de 1307, 1312 o 1318), Bernat de Font, escribano real, da cuentas a Bernat d'Aversó, notario real, de las gestiones hechas para la búsqueda de ciertos documentos en el depósito de San Juan de Jerusalén, de Barcelona. El documento lo localizó y transcribió Rafael Con$\mathrm{de}^{133}$. Es de un interés extraordinario, desde muchos puntos de vista. Trataremos de resumir los detalles más significativos para nuestro objeto. Bernat Font (que fue el escribano que despachó el recibo mediante el cual Jaime II reconoció a la priora de Sijena la entrega de la documentación real) cuenta a Aversó cómo, cuando regresó a Barcelona después de haber estado con él, se presentó el sábado anterior a la fecha de la carta en la casa de Aversó y, tras recoger las llaves que le dio su esposa, buscó in domo Hospitalis el instrumento papal que se le había encargado. Por dos veces buscó diligentemente entre omnibus instrumentis existentibus in illa caxia in qua sunt instrumenta papalia. No lo encontró ese día, ni tampoco el domingo por la mañana, aunque buscó en todas las cajas que pudo abrir (omnes caxias quas aperire potui, et nichil assimili inveni). Después de comer, y hasta la noche, continuó su búsqueda infructuosamente, aunque encontró algunas pocas noticias relacionadas entre los libros del rey Pedro. El lunes por la mañana siguió buscando con la ayuda de Pere Janer, escribano del rey. Miró de nuevo en la caja de los instrumentos papales, sin resultado. Finalmente, lo encontró perquisitis aliis caxiis, demum in caxia ubi sunt deponita instrumenta diversorum contractuum regiorum inveni transsumptum publicum instrumenti predicti; et ultimo, in majori caxia, inveni originale instrumentum predictum, quod iam retroacta die infra manus tenueram set, quia erat in eo suprascriptum "de facto Maioricarum», non curavi ipsum aperire licet quod omnia alia instrumenta quecumque suprascripcio esset in eis, aperuisse. Al punto hizo venir a un escribano para sacar traslado auténtico, como Aversó le había ordenado, lo que se hizo durante toda la tarde del lunes. Bernat de Font continúa su carta anunciando a Aversó que seguirá buscando otras noticias sobre los negocios que se le había comisionado, y da muchos y sabrosos detalles, que dejamos para otro momento.

132 CONDE, Rafael: Reyes y archivos... Se incluía también un memorial sobre documentos retirados de San Juan de la Peña.

133 CONDE, Rafael: Reyes y archivos..., doc. 31. 
Lo que nos interesa ahora es resaltar las dificultades que, en un momento inmediatamente posterior a la concentración de fondos documentales en el Hospital, se presentaron para la gestión eficaz de las búsquedas documentales, incluida el libramiento de copias y traslados. Vemos aquí cómo el «armario» al que se refería el rey en su orden a Botella de 1306, —y que en otros documentos posteriores denominan «archivo»- contenía bastantes cajas, algunas grandes, con un contenido más o menos homogéneo, aunque rotuladas confusamente. Las llaves de este armario las tenía en 1306 Pere March, escribano de ración, y en la fecha de la carta de Font $(1307,1312$ o 1318) el propio Bernat d'Aversó, quien durante su ausencia de Barcelona las había confiado a su mujer. La carta de Bernat Font a Aversó pone de manifiesto las limitaciones de una custodia no profesionalizada de la documentación (incluido el detalle de que la llave del archivo, en el que se custodian secretos del rey, queda a cargo de la esposa de un funcionario durante sus ausencias). El depósito documental del Hospital (el «armario» que se convierte en «archivo») estaba fuera de la Cancillería y, por tanto, fuera del circuito de producción de la documentación y de los centros de decisión políticos y administrativos. Por lo que llevamos visto, los depósitos reales en Sijena y en el Hospital se realizaron por orden del rey. De no mediar esta orden, los documentos reales quedaban dispersos, en poder de los oficiales reales que los tramitan o despachan, como ocurrió, por ejemplo, hacia 1309 con unos registros que se dejaron en el palacio del obispo de Valencia, canciller del rey, con el objeto de preservarlos del viaje que el rey Jaime II iniciaba hacia Almería ${ }^{134}$. En otro caso, encontramos documentación en poder del vizconde de Cardona, al cual en 1310 se le reclaman los registros producidos como procurador de Cataluña. En la orden de entrega, el rey manifiesta su admiración, non modicum admiramur, ante la actual negativa a entregarlos (anteriormente había ofrecido hacerlo), nam vos ignorare non credimus, qui dictum officium pro nobis exercuistis, quod registra ipsa racione ipsius officii et non alia de causa facta fuerunt, et ideo non potestis nec debetis penes vos modo aliquo retinere, en una clara y terminante afirmación del carácter público de la documentación generada por un oficial real, según Conde ${ }^{135}$.

El desarrollo de la práctica burocrática acarreó la necesidad, además, de consultar con frecuencia los antecedentes administrativos, ya no sólo por causa de los grandes negocios entre reyes, sino también de asuntos que afectaban a

${ }_{134}$ Certum est quod tempore supradicto dominus rex [Jaime II] recessit a civitate Valencie progrediens in viagium Granate, tumque presens et alia registra fuerunt dimissa de mandato regio in civitate Valencie in domo venerabilis in Christo patris domini Raimundi, episcopi Valencie et cancellarii domini regis. (ACA, Real Cancillería, Registros, núm. 206, f. 91. Citado y transcrito por BofaRull, Francisco de: (Historia...), doc. XXV; y por CONDE, Rafael: El archivo real del monasterio de Santa María de Sijena...) Bernat d'Aversó ordenó al escribano Pere Mas recoger un buen número de cartas partidas por $\mathrm{ABC}$ que retenía en su domicilio cierto escribano del Rosellón (MARTíNEZ FERRANDO, Jesús Ernesto: El Archivo de la Corona de Aragón..., p. 36).

135 ACA, Real Cancillería, reg. 238, f. 196 (Citado por CONDE, Rafael: Reyes y archivos...) 
diario a los particulares en su relación con la monarquía. Veamos un ejemplo coetáneo de cada caso. Respecto del primero, Stéphane Péquignot, en su estudio sobre la serie de registros conocida como Legationum, exhuma un interesante episodio ocurrido en enero de 1318 (sólo unos meses antes de la fundación del Archivo Real): Jaime II recibe de manos del embajador Jaspert de Castellnou una carta cerrada del rey Sancho de Mallorca, cuyo contenido le parece inaceptable, pues cuestiona la actuación de sus propios embajadores ante el monarca mallorquín. Jaime II ordena entonces buscar en los registros los artículos de la legación confiada a sus embajadores, a fin de mostrar inmediatamente al representante mallorquín las instrucciones registradas y replicar así a las protestas del rey Sancho. A petición de Jaspert de Castellnou, se realizó una copia de estos artículos para remitirla al rey de Mallorca ${ }^{136}$, (lo que demuestra la fe que se concede al documento registrado por un escribano real incluso por embajadores extranjeros). En el segundo caso, acaecido en 1315, Jaime II ordena consultar antecedentes administrativos de un asunto en los registros para comprobar la veracidad de una reclamación del almirante Francesc Carròs ${ }^{137}$. Esta vez pudo ejecutarse la consulta, acaso porque el registro estaba fácilmente localizable en el «archivo corriente» de la Cancillería. Pero en otras muchas ocasiones, el acceso diferido a la documentación debía generar dificultades y molestias burocráticas. Entre otras, a la hora de redactar inventarios para facilitar las búsquedas. Aunque hemos visto que el movimiento de documentación se acompañaba con albaranes (relaciones de entrega, se llamarían hoy) y se elaboraban memoriales (o inventarios, diríamos ahora) como el de Botella en 1306, son claramente insuficientes por falta de atención por parte de personal especializado que carece además del acceso fluido a los documentos que requiere este trabajo técnico.

Relacionado con este, hay otro factor a considerar. Tanto en Sijena (y otros depósitos medievales dispersos como San Juan de la Peña o Montearagón cuyo funcionamiento desconocemos) o en la casa del Hospital, la documentación del rey iba a parar, físicamente, a una casa que no estaba bajo su jurisdicción, aunque las llaves del armario en el que se colocaban los documentos estuvieran, como hemos visto, en poder de un oficial de la Cancillería. Pero no así el acceso al edificio, que correspondía a una instancia ajena a la Casa real. Por eso, ha de estar presente la priora o el comendador de cada casa. Son claros los problemas de toda naturaleza que se presentarían si los instrumentos jurídicos que demuestran los derechos y la superioridad de la soberanía regia estaban bajo la custodia y responsabilidad de un poder ajeno a la autoridad del rey y sometido a otras instancias jurídicas y políticas, como es la Iglesia. El archivo es marca de soberanía y deben conservarse en él los documentos emanados de la autoridad

136 PeQUignOT, S.: «Enregistrer, ordonner et contrôler: les documents diplomatiques dans les registra secreta de Jacques II d'Aragon», en Anuario de estudios medievales, 32/1 (2002), pp. 478-479.

137 Martínez Ferrando, Jesús Ernesto: Jaime II de Aragón. Su vida familiar, Barcelona, 1948, p. 295. 
regia y que demuestran su superioridad, tanto por razones jurídicas, como por otras de carácter político y aún de índole simplemente práctica. Lo demuestra con claridad meridiana un documento muy posterior de Fernando I, dado en 1413, pero impresionante, en el que se afirma:

car puys que les leys proceexen principalment del poder e actoritat del princep, encara que y entervenga assentiment de la Cort, raho dicta en ubert quels originals de aquellas deven esser en poder del princep de on dirivean e en son archiu, en lo qual son conservades totes altres scriptures fahens per dret real e de la terra, e fora fort impertinent cosa quels originals dels Usatges e Constitucions fossen fora del Archiu real, e que en dubte se hagues a recorrer a altre archiu e no al real138.

Por esta consideración general del archivo como depositario de los instrumentos que garantizan la soberanía regia —incluidos los documentos afectados por el secreto o que incumben exclusivamente a los intereses familiares y personales del rey, si es que en aquella época hubiera podido deslindarse el interés personal del monarca del interés del Estado- el depósito de documentos del soberano no podía estar bajo la custodia de una autoridad o instancia ajena a la estricta Casa real. Pero para ello era necesario tener desarrollados los principios teóricos y prácticos de lo que consiste la soberanía regia. Y también, la rutina administrativa y burocrática.

Jaume Riera ha sintetizado con precisión las circunstancias en las que nació el Archivo Real de Barcelona, núcleo del ACA. La cita es larga, pero nos evitará reiteraciones innecesarias:

«[El Archivo de la Corona de Aragón] nació como Archivo Real (...). Nació por el designio de un monarca meticuloso, que sabía esgrimir la documentación como arma legal y diplomática para incorporar territorios y jurisdicciones. Nació en 1318, cuando la cantidad de antiguas escrituras de la Casa Real, los archivos incautados a los Templarios (1307) y la complejidad de la documentación producida por su propia Cancillería movieron al rey Jaime II a destinar a archivo dos cámaras del Palacio que la construcción de la Capilla había dejado libres (...). La práctica de anotar en libros, primero en forma resumida y luego más extensamente, las cartas y las órdenes más importantes que la Cancillería sellaba y expedía empezó en los últimos tiempos del rey Conquistador, propiciada por la extensión del uso del papel. Prosiguió bajo sus dos inmediatos sucesores, pero fue el mismo Jaime II quien ordenó la copia íntegra de los documentos en series temáticas de registros, convirtiendo la registración previa del documento real a expedir en un trámite tan obligado como el mismo sellado»139.

138 ACA, Cancillería, reg. 2.381, fol. 27v.-28 (López RodríGuez, Carlos: «El Archivo Real de Barcelona...»)

139 [RIERA I SANS, Jaume]: Archivo de la Corona de Aragón, Ministerio de Educación, Cultura y Deporte, 1999, p. 1. 
Hemos visto que, en la primera década del siglo XIV, Jaime II había concentrado la documentación real en la casa del Hospital de Barcelona. Junto a este depósito, y en esta ciudad, existía al menos otro depósito de documentos reales en el propio palacio real, cuyo volumen ignoramos, pero del cual tenemos datos indudables de su existencia desde el reinado de Pedro III, aunque no antes. Estaba además el depósito o «archivo corriente» de la Cancillería real, cuyo aparato administrativo acompañaba al rey en su itinerancia por los reinos y dominios, pero que volvía periódicamente a sus oficinas de Barcelona, donde debía dejar parte de la documentación. Otra quedaba en poder de los escribanos y oficiales reales. En este contexto, se produjo la incorporación de los cuantiosos archivos de la Orden del Temple tras su extinción y confiscación. En estas circunstancias, la consulta de antecedentes, la garantía del secreto de la documentación y de su fe pública como consecuencia de una custodia ininterrumpida que garantice su veracidad e ingenuidad, el acceso y la expedición de copias autorizadas, y otros muchos detalles ligados a la conservación y custodia de un archivo como depósito con unas precisas condiciones jurídicas determinadas por el Derecho común, aconsejaron al rey fundar un archivo real pero ubicándolo en el corazón de la administración real y de la Cancillería regia, incorporado, a diferencia de los depósitos que le sirvieron como antecedentes, a la rutina administrativa de la expedición y conservación de los documentos. A ello contribuyó la mala situación por la que atravesaban el depósito real de documentos en la casa del Hospital, atenazado por la acumulación de escrituras e incapaz de absorberla eficazmente con la agilidad necesaria para permitir las búsquedas de documentos concretos, acumulación que también afectaría a las escribanías y otras oficinas reales, donde se amontonaban, a veces con muy poco control, los trescientos registros ya producidos cuando se materializó, en 1319, el archivo real creado en 1318 y la inmensa correspondencia que Jaime II iba acumulando.

En estas condiciones, Jaime II creó el archivo real en su palacio. Al retirar los depósitos de monasterios y conventos, el monarca demuestra que ya no le era necesaria la sanción de un lugar sagrado para protegerlos sino la suya propia. La operación queda testimoniada por el albarán de finiquito que el maestre racional Pere de Boil otorgó el 8 de mayo de 1319 a Arnau Messeguer, encargado de las reformas arquitectónicas que permitieran la instalación del archivo. En el albarán se recuerda que en el mes de julio de 1318 recibió éste la orden verbal de construir una cámara abovedada donde había estado la capilla del palacio real — tras la construcción, pues, de la capilla de Santa Águeda - en la cual fueran colocados los registres e.ls privilegis e.ls altres scrits de la sua cancelleria e dels altres fets de la sua cort; encima de ella, se debía construir otra cámara similar en la cual fossen conservades e estoyades les sues joyes d'aur e d'argent e les robes e els apparellaments de la sua cambra ${ }^{140}$. La conocida concepción medieval del archivo

${ }_{140}$ CONDE, Rafael: Reyes y archivos..., doc. 35. 
como «trésor des chartes», ya consagrada por un viejo trabajo de Bautier ${ }^{141}$, queda plasmada en esta proximidad física al propio tesoro real. Además, en el lugar dónde estaban los establos, debía construirse, por orden ya dada dos años antes, una tercera estancia con dos ventanas que diesen al patio del palacio en la qual casa fossen estoiats e conservats los comptes e les altres scriptures del offici del mestre racional de la sua cort ${ }^{142}$. Las obras se iniciaron el 6 de julio de 1318 y terminaron a finales de septiembre, con un presupuesto de 2.654 sueldos pagados por el baile general de Cataluña y el baile y el veguer de Barcelona ${ }^{143}$. Si se lee con detenimiento este documento, no se deduce de él que se fundara en ese momento el archivo, sino que se habilitaron unas determinadas estancias para destinarlas al archivo: de hecho, como hemos tratado de demostrar, un incipiente archivo real existía ya en Sijena y, más claramente, en la casa del Hospital de Barcelona antes de 1318.

Archivo real y archivo del maestre racional fueron en aquella época dos archivos diferentes. Del real se encargó un oficial de la escribanía al que algún documento regio llama tinent les claus del nostre archiu. El archivo real se encontraba muy vecino al salón del Tinell, en el espacio que ocupaba la capilla de la época condal, a los pies de la actual capilla de Santa Águeda, en lo que hoy se conoce como avantcambra. Probablemente se abría a ella ${ }^{144}$. De esta manera, además, el archivo real podía gozar, al menos en sus primeros años de vida, del privilegio de estar en un lugar que había sido sagrado, en el atrio de un templo, como en la antigüedad imperial romana, una imagen que habría de ser del agrado de los juristas romanistas de la corte de Jaime II.

\section{CONCLUSIÓN.}

El archivo real que nació en 1318 era lo que hoy llamaríamos «archivo definitivo». Como vimos, se mantuvo un archivo corriente en las escribanías de la Cancillería y de otros oficiales. Aunque siempre tuvo una inclinación natural a especializarse en la conservación de los registros de Cancillería, desde su fundación el Archivo Real de Barcelona tendió a constituirse como un archivo general de la Corona, y no sólo de la Cancillería. Por eso, muy pronto se incorporaron, en línea con la tradición de los depósitos del Hospital o de Sijena, además de los registros, toda la documentación de la Casa real que estuvo disponible: cuentas, procesos judiciales, relaciones de embajadores y confidentes, cartas familiares recibidas, etc.

141 BAUTIER, Robert-Henri: «La phase cruciale de l'histoire des archives: la constitution des depôts d'archives et la naissance de la archivistique (XVI ${ }^{\mathrm{e}}$-debut du $\mathrm{XIX}^{\mathrm{e}}$ siècle)», en Archivum, XVIII (1968), pp. 139-149.

142 CONDE, Rafael: Reyes y archivos..., docs. 179 y 180.

143 CONDE, Rafael: Reyes y archivos...

${ }^{144}$ CONDE, Rafael: Reyes y archivos... 
El precedente más inmediato del ACA no fue tanto Sijena (que sigue el modelo de un depósito de documentación muy primitivo) como el Hospital, que en su primera fase se constituyó a imitación de aquel, si bien más cercano a la residencia del rey en Barcelona, pero que después evolucionó hacia un nuevo modelo. Como hemos apuntado, su traslado al Palacio Real de Barcelona y su transformación en un auténtico archivo, sin las vacilaciones tan características de los momentos iniciales de una institución (que afectaron también a los registros de la cancillería, todavía en formación en tiempos de Jaime $\mathrm{II}^{145}$ ) está ligada no sólo a reformas meramente burocráticas, sino a un proceso más profundo de estatalización de la Monarquía, que, en el caso que nos ocupa, estuvo acompañado de las transformaciones acaecidas en el seno de la Corona de Aragón hasta transformarla de una mera agregación dinástica de territorios en una entidad política sustantiva. Con ánimo tan sólo de ilustrar este punto, recordaremos que el 14 de diciembre de 1318, apenas tres meses después de concluidas las obras de habilitación del archivo en el palacio real, se promulgó el estatuto por el cual los reinos de Aragón y Valencia, el condado de Barcelona y el dominio directo y los derechos pertenecientes al rey en el reino de Mallorca y en los condados de Rosellón y Cerdaña, en el Conflent, en el Vallespir y en los vizcondados de Omeladès y Carlat habrían de estar siempre unidos bajo un mismo dominio ${ }^{146}$. Este estatuto o privilegio fue jurado a partir de entonces por todos los reyes aragoneses, por lo menos hasta Alfonso el Magnánimo.

A tenor de lo que llevamos expuesto, el ACA se creó cuando la Corona de Aragón como unidad dinástica llevaba funcionando más de siglo y medio (desde 1137) y paralelamente a la transformación irreversible de esta unión dinástica en una entidad política, tras las alteraciones del siglo anterior. Fue el archivo en el que el rey, por razones de índole práctica, ordenó guardar inicialmente la documentación emanada de la corte y de la Cancillería real, es decir, de la oficina encargada de expedir los documentos que firmaba el monarca, única para todos los territorios de la Corona. Para su fundación, Jaime II mandó concentrar en este archivo de Barcelona los documentos que con anterioridad a 1318 se tenían depositados en diversos lugares e instituciones, sobre la base de la acumulación de fondos documentales que se había producido en los años anteriores en la casa de la Orden del Hospital en Barcelona, que a su vez había concentrado documentación procedente de diversos depósitos: el del monasterio de Santa María de Sijena (Huesca), el de San Juan de la Peña (Huesca), el de la Casa del Temple en Zaragoza, el de Montearagón, el de Santes Creus, más los existentes en otras casas de funcionarios, eclesiásticos y palacios reales dispersos por todos los reinos del rey de Aragón (como el de Calatayud), y los de algunas comandas catalanas del Temple, como las de Barberà $o$

${ }^{145}$ Lo ha demostrado recientemente PÉQUIGNOT, S.: «Enregistrer, ordonner et contrôler...»., pp. 431-479.

146 ACA, Real Cancillería, reg. 217, fols. 224-225. 
Barcelona. Por ello, desde sus inicios, el Archivo Real de Barcelona, como la Cancillería, fue también único para toda la Corona de Aragón. En el siglo XV, sin embargo, se crearon el Archivo del Real de Valencia (1419) y luego el de Zaragoza (1461), pero sólo para los documentos relativos a cada uno de esos reinos. En el de Barcelona se continuó guardando la documentación del rey expedida por la Cancillería de carácter general, sin un alcance territorial específico, además de la relativa a Baleares, Cerdeña, Sicilia y Nápoles (para estos dos últimos reinos, sólo durante el siglo XV), junto con la del Principado de Cataluña y los condados de Rosellón y Cerdaña. La naturaleza del Archivo Real como oficina documental central de la monarquía es una de sus características más reseñables (y quizá la que explica su supervivencia secular). No obstante, aunque en 1318 había comenzado su andadura, que no se ha interrumpido hasta hoy, todavía le quedaba entonces para su sanción institucional definitiva dos elementos, que adquirió a lo largo del siglo XIV: la asignación de medios personales estables y su regulación normativa. Tras su fundación, el jefe del real archivo era el notario guardasellos (que lo fue Bernat d'Aversó desde 1301) y, en su ausencia, se encargaba el escribano del Palacio. El 6 de julio de 1346, Pedro el Ceremonioso nombró a su escribano de registro Pere Perseya como archivero, eximiéndole de la obligación de seguir a la corte para ocuparse del Archivo, que se convertía así en una oficina permanente de trabajo documental. Por último, el funcionamiento del Archivo quedó fijado en unas ejemplares Ordenanzas promulgadas también por Pedro el Ceremonioso en 1384. En ellas se detallaban los documentos que tenían que guardarse, el tratamiento que habían de recibir y los deberes del archivero ${ }^{147}$.

Como dijo Martínez Ferrando, el natural amor a las cosas de la tierra no nos debe llevar a desenfocar los orígenes del ACA y a tratar de remontarlo, mediante suposiciones, a épocas demasiado remotas ni a cambiar su carácter. Tampoco es necesario para ensalzar este gran archivo, aunque sí, por lo que vemos en los últimos tiempos, para destruirlo. Con independencia del momento exacto de su nacimiento, la historia del ARB, transmutado después en ACA, ha sido hasta hoy la de una empresa exitosa que ha sobrevivido milagrosamente durante siete siglos a todo tipo de avatares. El ACA, acaso la institución archivística viva más antigua de Europa, es producto de este proceso histórico de acumulación documental que es consustancial a su génesis y formación, y que se ha ido repitiendo constantemente. Pero ésta es ya otra historia.

${ }_{147}$ CONDE, Rafael: Les primeres ordinacions...; [RIERA I SANS, Jaume]: Archivo de la Corona de Aragón..., p. 2. 